\title{
Type III Intermediate Filaments Desmin, Glial Fibrillary Acidic Protein (GFAP), Vimentin, and Peripherin
}

\section{Elly M. Hol ${ }^{1,2,3}$ and Yassemi Capetanaki ${ }^{4}$}

${ }^{1}$ Department of Translational Neuroscience, Brain Center Rudolf Magnus, University Medical Center Utrecht, 3584 CG Utrecht, The Netherlands

${ }^{2}$ Netherlands Institute for Neuroscience, an Institute of the Royal Netherlands Academy of Arts and Sciences, 1105 BA Amsterdam, The Netherlands

${ }^{3}$ Swammerdam Institute for Life Sciences, Center for Neuroscience, University of Amsterdam, 1098 XH Amsterdam, The Netherlands

${ }^{4}$ Center of Basic Research, Biomedical Research Foundation Academy of Athens, Athens 11527, Greece

Correspondence: ycapetanaki@bioacademy.gr; e.m.hol-2@umcutrecht.nl

\section{SUMMARY}

Type III intermediate filament (IF) proteins assemble into cytoplasmic homopolymeric and heteropolymeric filaments with other type III and some type IV IFs. These highly dynamic structures form an integral component of the cytoskeleton of muscle, brain, and mesenchymal cells. Here, we review the current ideas on the role of type III IFs in health and disease. It turns out that they not only offer resilience to mechanical strains, but, most importantly, they facilitate very efficiently the integration of cell structure and function, thus providing the necessary scaffolds for optimal cellular responses upon biochemical stresses and protecting against cell death, disease, and aging.

\section{Outline}

\begin{tabular}{l|l}
1 Introduction & 5 Vimentin \\
2 Desmin & 6 Conclusion \\
3 GFAP & References \\
4 Peripherin &
\end{tabular}




\section{INTRODUCTION}

There are four proteins classified as type III intermediate filament (IF) proteins: desmin, glial fibrillary acidic protein (GFAP), peripherin, and vimentin. Desmin is expressed in all muscle types, GFAP is expressed in astrocytes and other glial cells, and peripherin is expressed in peripheral neurons. Vimentin is the most widely distributed and studied type III IF protein, expressed mainly in mesenchyme-derived cells, undifferentiated cells, and most cells in culture. Type III IF proteins can form coiled-coil dimers with themselves, other type III IF members, and type IV IF proteins such as syncoilin, nestin, neurofilaments, and synemins. All type III IF proteins are cytoplasmic IFs and have a similar primary structure, consisting of a head, rod, and tail domain (Fig. 1). Here, we review the expression of the different type III IFs during development and in adulthood, before moving on to focus on their role in health and disease.

\section{DESMIN}

\subsection{Desmin in Muscle Development}

\subsubsection{Expression Pattern in Cardiac and Skeletal Muscle Progenitors}

The original cloning of desmin complementary DNA (cDNA) (Capetanaki et al. 1984) has facilitated molecular studies related to the gene encoding desmin and the role of desmin protein in health and disease (Capetanaki et al. 2015). Desmin is one of the earliest detected muscle-specific proteins during mammalian embryonic development
(Capetanaki 2002; Capetanaki et al. 2015), appearing first at day 7.5 postcoitum in the precardial mesoderm, and a day later in the skeletal muscle progenitors, the myotome of the somites, in which its expression precedes even the myogenic helix-loop-helix (HLH) transcription regulators MyoD, myogenin, and MRF4 (Buckingham et al. 1992). All these factors, in cooperation with members of the MEF2 family of transcription regulators, control desmin expression during development ( $\mathrm{Li}$ and Capetanaki 1994; Kuisk et al. 1996), thus suggesting a regulatory role for desmin during myogenic commitment and differentiation. Desmin is also expressed in adult skeletal and cardiac muscle progenitor cells (Allen et al. 1991; Pfister et al. 2005).

\subsubsection{Nuclear Role as a Myogenic and Cardiogenic Cytoskeletal Regulator}

During myogenesis and cardiogenesis, extensive mechanochemical signal transduction from the cell surface to the nucleus takes place, and the IF cytoskeletal and nucleoskeletal systems are potential modulators of such actions because they form a continuous network that links directly or through the LINC ("linker of the nucleoskeleton and the cytoskeleton") complex, the outside of the cell to the nuclear interior (Capetanaki et al. 2007). Desmin is very important for myogenic and cardiogenic differentiation. Inhibition of desmin expression interferes not only with myoblast fusion and myotube differentiation but also with proper expression of the myogenic transcription regulators MyoD and myogenin in C2C12 cells (Li et al. 1994)

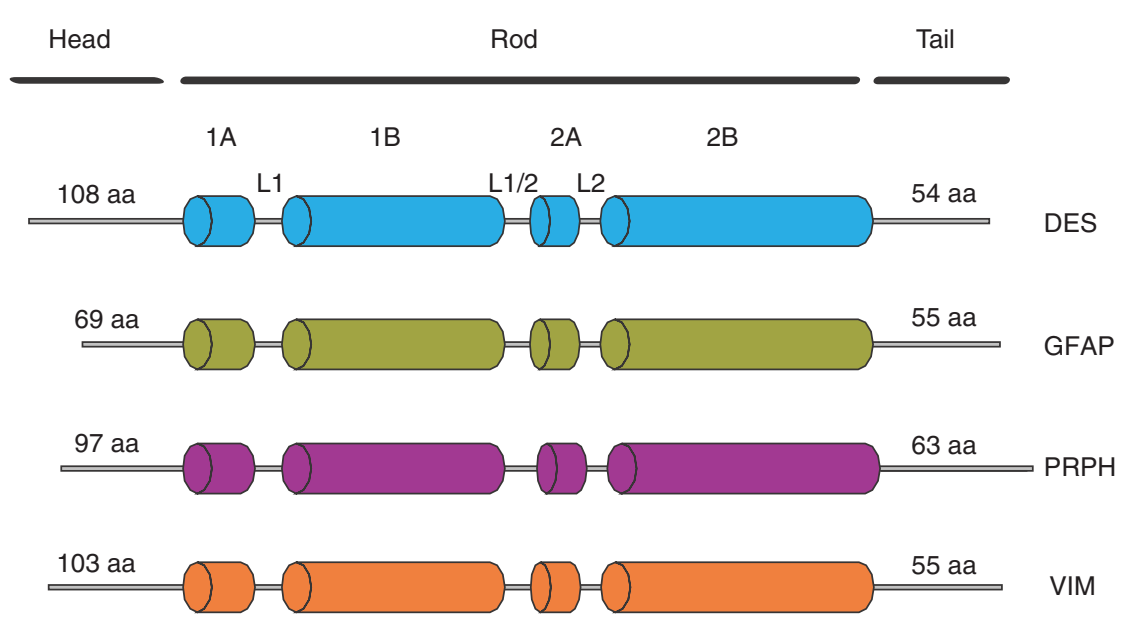

Figure 1. A schematic overview of the type III intermediate filaments (IFs) (only the human form is shown). The three IF domains-head, rod, and tail—are indicated. The rod domain is divided into subregions: the coiled-coil regions 1A (35 aa), 1B ( $8 \mathrm{aa}), 2 \mathrm{~A}$ (19 aa), and 2B (121 aa); and these subregions are separated by linker regions L1 (8 aa), L1/2 (DES, GFAP, and VIM, 16 aa; PRPH, 18 aa), and L2 ( 8 aa). The most variability in amino acid length is present in the head and tail region. aa, amino acids; DES, desmin; GFAP, glial fibrillary acidic protein; L, linker; $\mathrm{PRPH}$, peripherin; VIM, vimentin. 
and, additionally, of myf5 in desmin-deficient $\left(\right.$ des $\left.^{-/-}\right)$ embryoid bodies (EBs) (Weitzer et al. 1995). Furthermore, mutations of desmin interfere with cardiogenesis and are linked to down-regulation of brachyury, goosecoid, nkx2.5, and Mef2c, all important cardiogenic regulators (Hollrigl et al. 2002; Hofner et al. 2007; Hollrigl et al. 2007), whereas ectopic expression of desmin in embryonic stem cells promotes up-regulation of brachyury and nkx2.5 (Hofner et al. 2007). All the above findings strongly suggest that the desmin cytoskeleton facilitates commitment of primitive mesoderm to cardiogenic and myogenic lineages or the maintenance of the committed lineages and subsequent differentiation, as well as maintenance of proper skeletal and cardiac muscle homeostasis and regeneration in adulthood.

How could desmin be involved in these processes? As discussed above, it could act as the mechanosensor and transducer of mechanical forces to the nucleus, a hypothesis supported by studies demonstrating that nuclear shape and positioning, as well as links to sarcomeres, are altered in desmin-null mice (Capetanaki et al. 1997; Shah et al. 2004; Ralston et al. 2006), whereas lamin A/C-deficient cardiomyocytes show detachment of desmin IFs from the nuclear surface and progressive disruption of its network (Nikolova et al. 2004). In addition, lamin $\mathrm{A} / \mathrm{C}$ and emerin (Adam 2016) are crucial for skeletal muscle satellite cell differentiation, and restoration of normal desmin levels in $L m n A^{-/-}$myoblasts enhances their differentiation potential (Frock et al. 2006). Finally, very recent novel data have shown that desmin enters transiently the nucleus of cardiac stem cells, physically interacts with transcription factor complexes bound to the enhancer and promoter elements of the $N k x 2.5$ gene, and regulates its transcription (Fuchs et al. 2016).

\subsection{Desmin in Adult Muscle Maintenance}

\subsubsection{Mechanochemical Integrator of Muscle Structure, Maintenance, and Function}

Adult striated muscle is a highly organized tissue (Fig. 2), with direct links between morphology and function, and effective mechanochemical signaling among the contractile apparatus and the nucleus and other organelles. Maintenance of this high level of integration requires a cell-wide system that has the potential to interact with all the key structures involved. A good candidate for such a system is the desmin IF cytoskeleton that surrounds the Z-disks and interconnects the contractile apparatus to the sarcolemma, at the level of costameres and at intercalated disks in the case of cardiac muscle (Figs. 2 and 3), as well as to different membranous organelles, including the nucleus, mitochon- dria, lysosomes, and potentially the sarcoplasmic reticulum (Capetanaki et al. 2007; Capetanaki et al. 2015). The molecular mechanism responsible for the majority of these associations remains unknown.

\subsubsection{Links to Membranous Organelles}

Desmin and the sarcolemma/intercalated disks (costamere organization and function). Desmin IFs associate with the sarcolemma of both cardiac and skeletal muscle at structures termed "costameres," present at the membrane overlying Z-disks. In addition, in cardiac muscle, desmin associates with the desmosomes of the intercalated disks through desmoplakin (Capetanaki et al. 2015). Studies with desmin-deficient mice have shown that desmin IFs play an important role in stabilizing the organization of the sarcolemma into costameres (O'Neill et al. 2002; Capetanaki et al. 2007).

Desmin links to nuclei/mechanochemical signaling. Although the nuclear envelope seems to isolate the cytoplasmic from the nuclear IF scaffold, these two systems form a continuous network, either directly through the nuclear pores (Capetanaki et al. 2007; Capetanaki et al. 2015) or through the association of the cytoskeletal cross-linking protein plectin and the LINC-complex protein nesprin 3. This association provides linkages between cytoskeletal IFs and lamins $\mathrm{A} / \mathrm{C}$ and the nuclear envelope protein emerin through interactions with SUN1 and SUN2 proteins (Wilhelmsen et al. 2005). These interactions are consistent with the importance of desmin shown in the proper localization of myofiber nuclei (Ralston et al. 2006), the mechanical coupling of the contractile apparatus and the nucleus (Shah et al. 2004), and, consequently, the lamin-based nucleoskeleton. Based on these findings, it has been proposed that the desmin IF scaffold could participate in a bidirectional mechanochemical signaling process leading to de novo gene activity and tissue homeostasis. This hypothesis is supported by the established interaction of desmin with myospryn (Kouloumenta et al. 2007), a negative modulator of calcineurin (Kielbasa et al. 2011; Tsoupri and Capetanaki 2013), as well as its suggested interaction with the stretch-sensing transcription factor cardiac ankyrin repeat protein (CARP) (Witt et al. 2005). Finally, an additional novel interaction of desmin with the homologous transcription factors Dux4 and Dux4c in the cytoplasm and at the nuclear periphery during muscle differentiation was recently reported (Ansseau et al. 2016). As discussed below, IFs are also associated with other membranous organelles in the myoplasm, thus, potentially facilitating the cross talk required for efficient muscle function.

Desmin links to the biogenesis, maintenance, and function of mitochondria. Alterations in mitochondrial distri- 

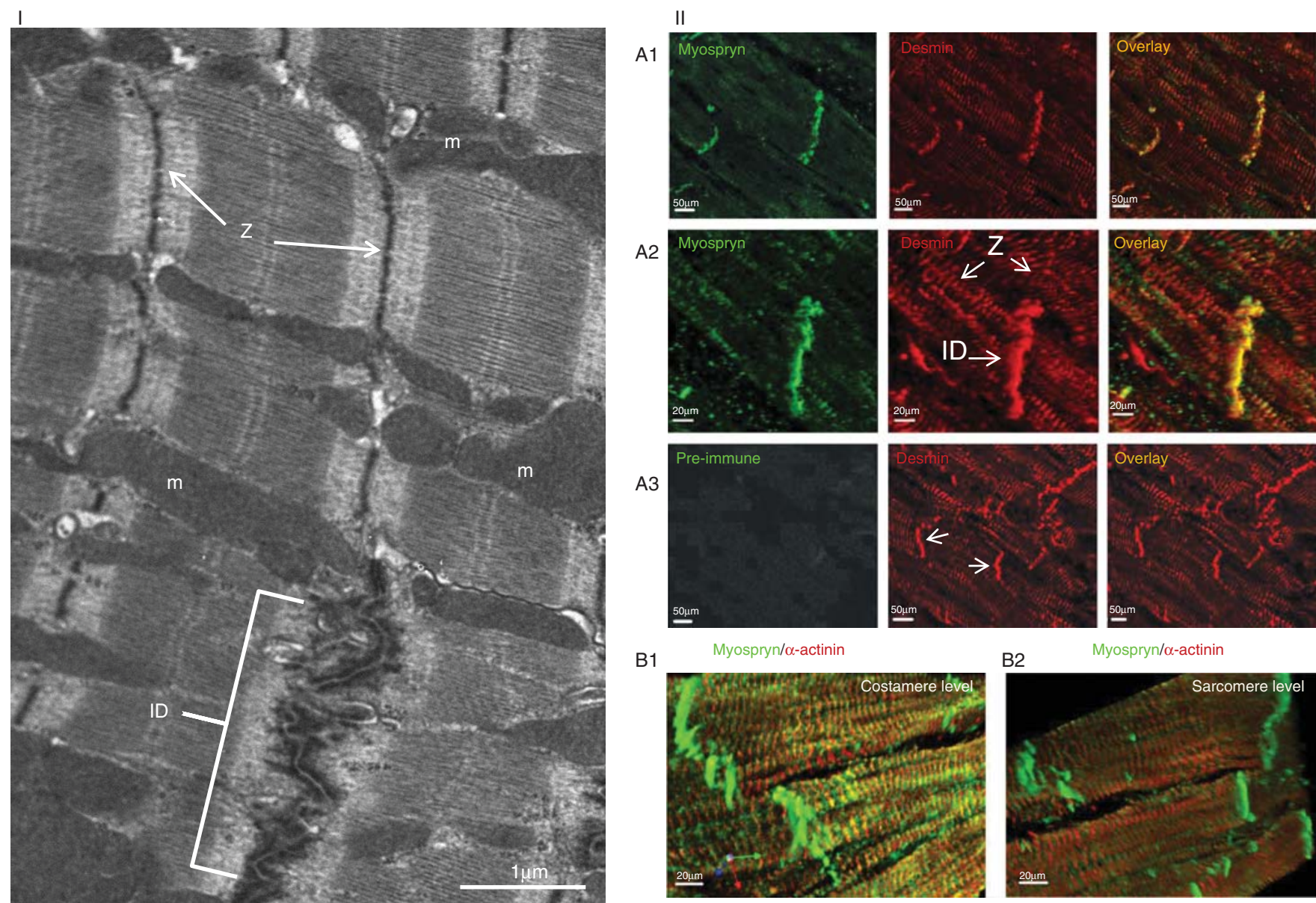

A2
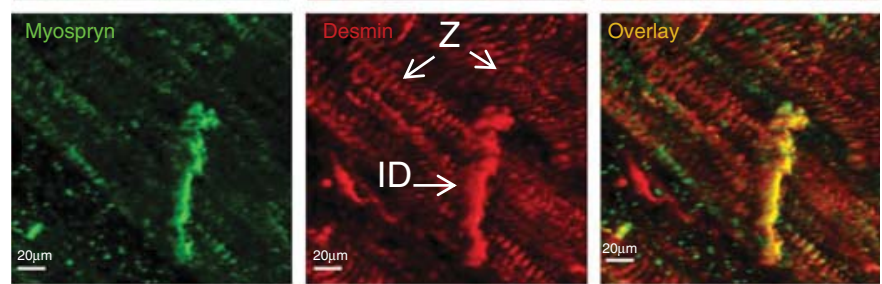

A3
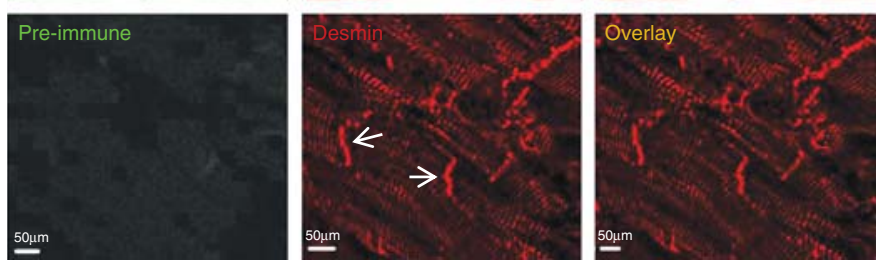

B1

Myospryn/ $\alpha$-actinin

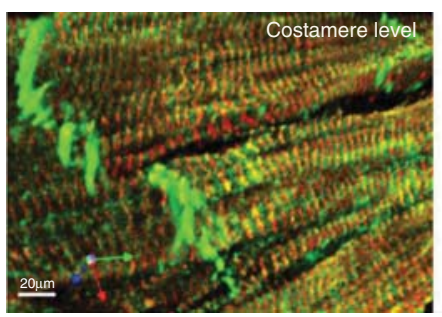

B2

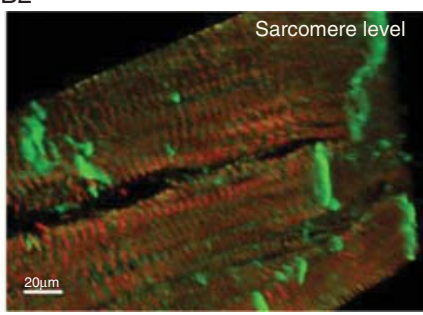

Figure 2. Localization of desmin and its associated protein myospryn in cardiac striated muscle. (I) Electronmicroscopic ultrastructural view of the mouse myocardium showing intercalated disks (ID), Z-disks (Z), and mitochondria (m). (II) Colocalization of desmin (red) and myospryn (green) by immunofluorescence microscopy. IDs and Z-disks (Z) are indicated in panel $I$ and the middle figure of panel IIA2; IDs are also indicated in panel IIA3 (middle) by arrowheads. $(B 1, B 2)$ In contrast to ID and costameres, myospryn (green) is not detectable at the internal sarcomeric Z-discs. $\alpha$-actinin (red) is used as positive Z-disc marker. Not shown here, desmin is also localized at the costameres. Scale bars, $1 \mu \mathrm{m}$ (I), $20 \mu \mathrm{m}$ (IIA2, IIB1, IIB2), and $50 \mu \mathrm{m}$ (IIA1, IIA3). (II, Adapted from Kouloumenta et al. 2007.)

bution and morphology are associated with normal cellular processes, as well as with a variety of pathological conditions, including muscular dystrophy and cardiomyopathy. Mitochondria are linked directly or indirectly to microfilaments, microtubules, and-of most interest here-IFs (Rappaport et al. 1998). The first findings on the interplay between the desmin IF cytoskeleton and mitochondria came from studies with desmin-deficient mice (Milner et al. 2000; Capetanaki 2002). The absence of desmin leads to mitochondrial defects, followed by cardiomyocyte death, inflammation, fibrosis, and calcification, all leading to extensive myocardial degeneration, dilated cardiomyopathy, and heart failure (Li et al. 1996; Milner et al. 1996; Kay et al. 1997; Milner et al. 1999; Milner et al. 2000; Mavroidis and Capetanaki 2002; Psarras et al. 2012; Mavroidis et al.
2015). Mitochondrial abnormalities seem to be the earliest detected defects in desmin-null myocytes and include loss of proper morphology, cristae structure, respiratory function, abnormal mitochondrial permeability transition pore (mPTP) activation, and dissipation of mitochondrial membrane potential $(\Delta \psi)$ (Milner et al. 2000; Diokmetzidou et al. 2016). This is consistent with the observation that mitochondrial abnormalities are ameliorated by overexpressing $\mathrm{Bcl} 2$, an antiapoptotic protein located at the mitochondrial contact sites and known to regulate mPTP function (Weisleder et al. 2004). A link between mitochondrial $\Delta \psi$ and vimentin has also been reported (Chernoivanenko et al. 2015). The observed loss of mitochondrial positioning could be a secondary effect, at least in cardiomyocytes, given that overexpression of $\mathrm{Bcl} 2$ in the desmin- 


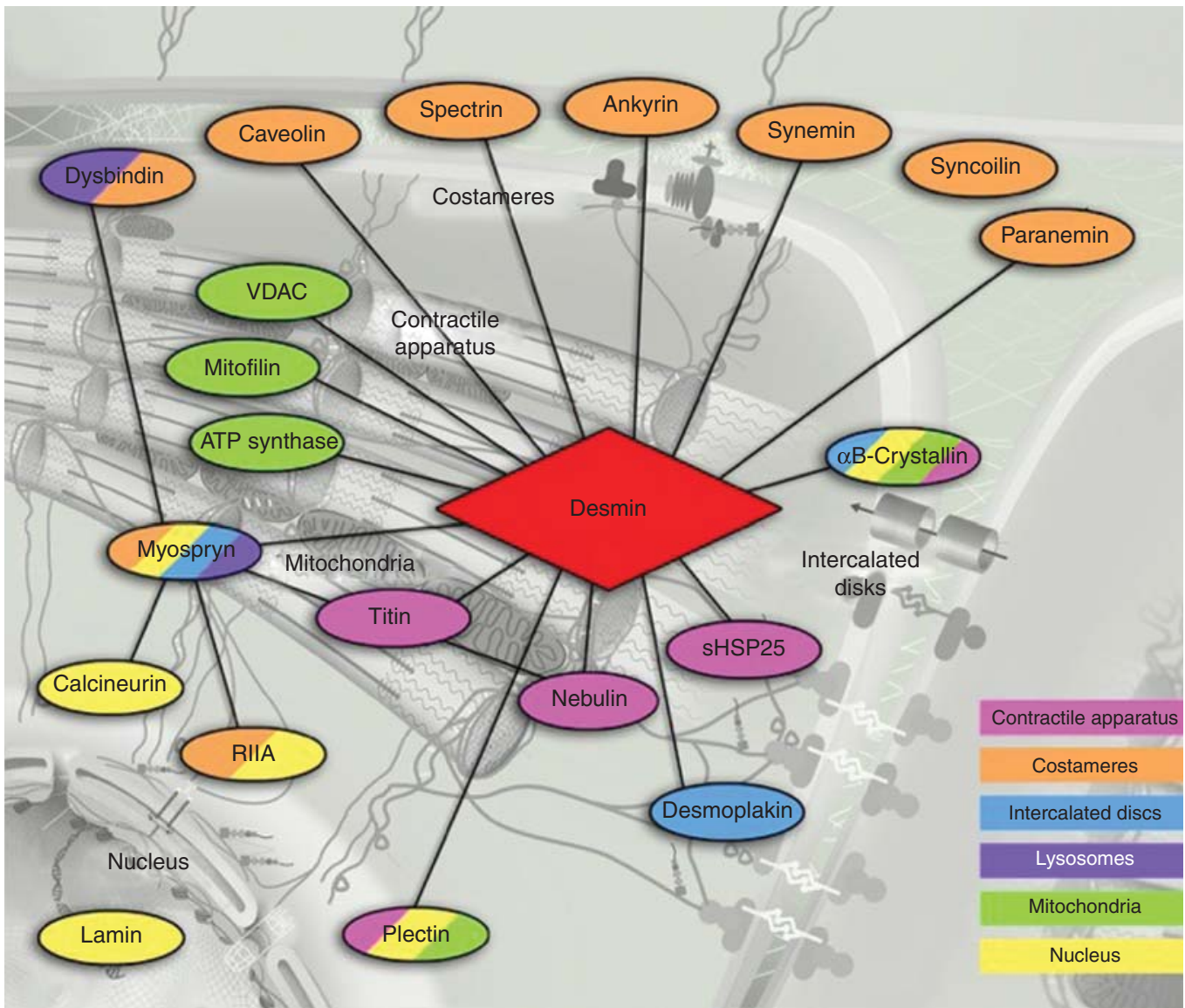

Figure 3. Current state of the desmin interactome. Known direct connections of desmin with proteins of different cardiomyocyte compartments are presented. The different colors indicate the corresponding compartment that the desmin-associated proteins are localized to (see key, lower right). The positions of these compartments are indicated in the typical cardiomyocyte diagram shown as a neutral background (adapted from Capetanaki et al. 2015). Proteins localized in multiple compartments are shown with the corresponding multiple colors. Only a few proteins (dysbindin, calcineurin, and RIIa) are shown that connect indirectly to desmin —all through myospryn. RIIa, regulatory subunit of cAMP-dependent kinase; VDAC, voltage-dependent anion channel.

null heart corrects this defect (Weisleder et al. 2004). Similar mitochondrial abnormalities have been observed in patients with mutations in desmin (Clemen et al. 2013; Capetanaki et al. 2015), as well as in other IF proteins, including neurofilament NF-L (Brownlees et al. 2002) and keratins K5 and K14 (Uttam et al. 1996), causing neuronal and epithelial disorders, respectively.

How can the desmin IF cytoskeleton influence mitochondria behavior and function? Desmin IFs could stabilize mitochondria near other organelles required for their functional cross talk, such as endoplasmic reticulum/sarcoplasmic reticulum (ER/SR) (Capetanaki et al. 2007). They might also directly influence mitochondrial membrane behavior either by supporting proper protein and lipid targeting to the right compartments or by stabilizing properly targeted functional complexes, as initially suggested by mitochondrial proteome comparisons between wildtype and desmin-null hearts (Fountoulakis et al. 2005).
Indeed, very recently it was shown that desmin is localized at the contact sites between SR and mitochondria (MAMs, mitochondria-associated membranes), established sites for multiple cellular processes, including $\mathrm{Ca}^{2+}$ and metabolite transfer, lipid metabolism, mitochondrial shape regulation, and autophagosome and inflammasome formation (Diokmetzidou et al. 2016). This association could be mediated through VDAC (voltage-dependent anion channel), which was also found to associate with desmin. In addition, desmin associates with different members of the MICOS (contact site and cristae organizing system) complex and ATP synthase, consistent with the cristae defects, the decreased levels of mitofilin (Mic60), other mitochondrial proteins, and ATP levels in desmin-deficient cardiomyocytes (Diokmetzidou et al. 2016). As discussed below, of great interest is the finding that the desmin-associated chaperone $\alpha \mathrm{B}$-crystallin was also found to associate with the same mitochondrial proteins and, when overexpressed 
in desmin-deficient hearts, all mitochondrial defects were ameliorated (Diokmetzidou et al. 2016).

Desmin links to lysosome-related organelles. It was recently suggested that desmin is potentially involved in vesicle trafficking and lysosome-related organelle biogenesis through its associated protein myospryn (Kouloumenta et al. 2007). Desmin is essential for the proper positioning of lysosomes, suggesting a potential role for desmin IFs and associated proteins in the control of the endo/lysosomal compartments and proper lysosome biogenesis and distribution in cardiomyocytes (Holen et al. 1992; Blankson et al. 1995).

\subsection{Desmin Interactome}

Investigations with desmin have revealed that, as expected, this multifunctional protein forms a very complex interactome. Desmin interacts directly with more than 15 proteins and indirectly, most possibly, with the entire muscle mechanochemical interactome. IFs, in general, and desmin, in particular, have also been suggested to interact with DNA (Traub 1995). Here, we will mainly focus on putative direct interactions. These interactions (Fig. 3) can be operationally divided into interactions with (1) other members of the IF family, (2) proteins of the contractile apparatus, (3) proteins linking to the costameres, (4) proteins linking to the intercalated disks, (5) proteins linking to the nucleus, (6) proteins linking to mitochondria, (7) proteins linking to lysosomes, (8) chaperone proteins linking to multiple sites, and (9) others.

IF partners. Four cytoplasmic IF proteins interact with desmin, one type III IF protein, vimentin, and three type IV, synemin, and syncoilin, at the Z-disk and costamere levels (Poon et al. 2002), and nestin. Desmin also interacts with nuclear lamin B (Georgatos and Blobel 1987; Cetin et al. 2013). Desmin can form heteropolymers with vimentin and nestin (not with its avian ortholog paranemin) but not with synemin and syncoilin (Clemen et al. 2013).

Proteins comprising the contractile apparatus. At the level of Z-disks of the myofibrils, desmin associates with the plectin isoform 1d (Konieczny et al. 2008), nebulin (Bang et al. 2002; Conover and Gregorio 2011), and nebulette (Hernandez et al. 2016).

Proteins linking to the costameres. In addition to synemin and syncoilin, desmin associates with costameres through linkages to different proteins, including the plectin isoform If (Konieczny et al. 2008), spectrin (Langley, Jr. and Cohen 1986), and potentially ankyrin (Georgatos and Blobel 1987). As mentioned above, desmin also associates with the novel TRIM (tripartite motif family)-like protein myospryn (Kouloumenta et al. 2007; Tsoupri and Capetanaki 2013), which also localizes at the costameres and in- teracts with the dystrophin complex through dysbindindystrobrevin (Fig. 2; Benson et al. 2004; Kouloumenta et al. 2007). There is evidence that both caveolin 3 (Mermelstein et al. 2007) and the nicotinic acetylcholine receptor located at the motor end plate (Mitsui et al. 2000) also interact with desmin.

Proteins linking to the intercalated disks. At the level of intercalated disks, desmin associates with desmoplakin (Kartenbeck et al. 1983; Lapouge et al. 2006) and myospryn (Fig. 2; Kouloumenta et al. 2007) through its tail and head domain, respectively.

Proteins linking to the nucleus. As discussed above, plectin, through its interactions with nesprin 3 and lamins, is involved in the association between desmin IF and the nucleus. The established localization of myospryn around the nucleus requires desmin (Kouloumenta et al. 2007). Therefore, myospryn does not seem to mediate the association of desmin IFs to the nucleus. In contrast, myospryn, either as an A-kinase anchoring protein (AKAP) or as a calcineurin modulator, seems to regulate calcineurin-dependent transcriptional activity and regeneration (Kielbasa et al. 2011; Tsoupri and Capetanaki 2013). Although there is no evidence yet, this phenomenon could be linked to the direct nuclear actions of desmin described above (Fuchs et al. 2016).

Proteins linking to mitochondria. One of the proteins that mediates the association of desmin IFs to mitochondria is plectin isoform $1 \mathrm{~b}$, but how plectin associates with mitochondria is unknown. It should be mentioned that trichoplein, a novel keratin-binding protein with some homology with plectin, associates with the outer mitochondrial membrane and reduces mitochondrial motility (Cerqua et al. 2010). Myotubularin is a more recently identified desmin-associated protein, and mutations responsible for loss of this association are linked to mitochondrial defects and X-linked centronuclear myopathy (Hnia et al. 2011). As mentioned above, several mitochondrial proteins have been found to associate directly or indirectly with desmin (Diokmetzidou et al. 2016); these include VDAC, the MICOS complex members Mic60, Mic19, and Mic27, the OMM Sam50, involved in protein transport, and OPA1, involved in fusion, and ATP synthase $\beta$. At least the interaction with VDAC is direct and takes place between the desmin carboxyl terminus and the VDAC amino terminus. Whether VDAC is the mediator of the interaction of desmin with MICOS remains elusive. In addition to all the transport processes mentioned above, the desmin-mediated connection of sarcomeres to all these mitochondrial proteins could facilitate signal transmission of the muscle energy demands directly to mitochondria, thus coupling mechanochemical signaling to metabolism and controlling life-and-death decisions. 
Proteins linking to lysosomes. As discussed above, desmin associates with the biogenesis of lysosome-related organelles complex 1 (BLOC-1), which is involved in protein trafficking and organelle biogenesis through myospryn (Kouloumenta et al. 2007), the muscle-specific partner of dysbindin, a component of BLOC-1 (Benson et al. 2004).

Chaperone protein links at multiple sites. Desmin associates with the small heat-shock proteins hsp25/27 and $\alpha$ Bcrystallin (Bennardini et al. 1992; reviewed in Wettstein et al. 2012), and colocalizes with them at multiple sites. This association seems to be of great importance for both partners and reflects a very interesting mito- and cardioprotective interplay between them (Diokmetzidou et al. 2016). As has been shown recently, overexpression of $\alpha \mathrm{B}$-crystallin in desmin-deficient hearts ameliorates all mitochondrial defects and improves cardiac function significantly. Given that $\alpha B$-crystallin was also found to interact with all mitochondrial proteins found to interact with desmin, this extensive cardioprotection is linked to these associations, proper mitochondrial-SR cross talk, proper mitochondrial protein levels, inhibition of abnormal mPTP activation, and maintenance of $\Delta \psi$ (Diokmetzidou et al. 2016).

Others. Desmin associates with calponin, a calmodulinand tropomyosin-binding protein, at least in smooth muscle (Fujii et al. 2000). Finally, surfactant protein A (SP-A), a member of the collectin family that regulates innate immunity, associates with desmin and vimentin and regulates their polymerization (Garcia-Verdugo et al. 2008).

\subsection{Desmin in Disease}

Mutations in the desmin gene (DES) or abnormal posttranslational modifications cause cardiac and skeletal myopathies, collectively called desmin-related myopathies (DRMs) or desminopathies (Goldfarb and Dalakas 2009; Capetanaki et al. 2015). Nearly 70 human DES mutations associated with desminopathy have been reported so far, most of them localized within coil $2 \mathrm{~B}$, which is an important domain for IF assembly (Clemen et al. 2013; Herrmann and Aebi 2016). Indeed, the majority of desmin mutants cannot form a de novo desmin IF network-instead, they form non-IF structures and protein aggregates, leading to loss of function of both desmin and its binding partners, as well as potential toxic effects of the formed aggregates. The most common desmin-related heart disease was recently suggested to be tumor necrosis factor alpha (TNF- $\alpha$ )-induced heart failure (Panagopoulou et al. 2008). TNF- $\alpha$ increase is the hallmark of all heart failure models. Activation of caspases by TNF- $\alpha$ leads to desmin cleavage and aggregate formation both in mouse and human (Panagopoulou et al. 2008; Papathanasiou et al. 2015), intercalated disk destabilization, mitochondrial defects, cell death, and heart failure. It is important to note that, so far, two transgenic strategies have ameliorated desmin-related disease, one by overexpression of Bcl2 (Weisleder et al. 2004) and the other by overexpression of $\alpha B$-crystallin (Diokmetzidou et al. 2016). In both cases, rescue of the mitochondrial defects is the hallmark, with $\alpha \mathrm{B}$-crystallin showing an unexpected superior rescue, resembling a wild-type heart. Finally, of great interest is the recent finding that TNF- $\alpha$-induced ectopic expression of keratins K8 and K18 in the desmin-deficient myocardium and other heart failure models rescues both mitochondrial and intercalated disk disease defects (Papathanasiou et al. 2015).

\section{GFAP}

GFAP was originally discovered in brain tissue of multiple sclerosis patients (Eng et al. 1971). In 1984, Lewis and colleagues were the first to isolate a nearly complete cDNA clone for mouse GFAP, marking a new era of molecular studies related to the GFAP gene (Lewis et al. 1984). A few years later, the human GFAP gene was cloned (Reeves et al. 1989) and, in time, sequences of other species became available. GFAP is the signature IF of astrocytes, a specific type of glia, which are a class of nonneuronal cells in the central nervous system (CNS). GFAP messenger RNA (mRNA) and protein are tightly regulated during development, marking the maturation of astrocytes, and GFAP is up-regulated in reactive astrocytes in disease (Eng et al. 2000; Middeldorp and Hol 2011). Figure 4 shows GFAP IFs in human astrocytes, the human GFAP $\alpha$ IF network formed in mouse embryonic fibroblasts $\left(\mathrm{MEF} \operatorname{vim}^{-/-}\right.$), and human GFAP $\alpha$ integrated in the endogenous IF network in mouse primary astrocytes.

\subsection{GFAP in Development of the Nervous System}

\subsubsection{Expression in CNS, Peripheral Nervous System, and Enteric Nervous System}

GFAP is considered to be a marker for fully differentiated astrocytes in the nervous system, but is also expressed in fetal and adult neural stem cells. The expression of GFAP mRNA and protein starts early in development in the radial glia, the neural stem cells of the developing CNS. In mouse brains, GFAP is expressed as of embryonic day E9.5 (Fox et al. 2004) and in human radial glia at approximately gestational week 13 (Middeldorp et al. 2010). In human myenteric ganglion cells, GFAP protein has been reported as early as gestational week 10 (Fekete et al. 1999). In the adult nervous system, GFAP is expressed in mature astro- 

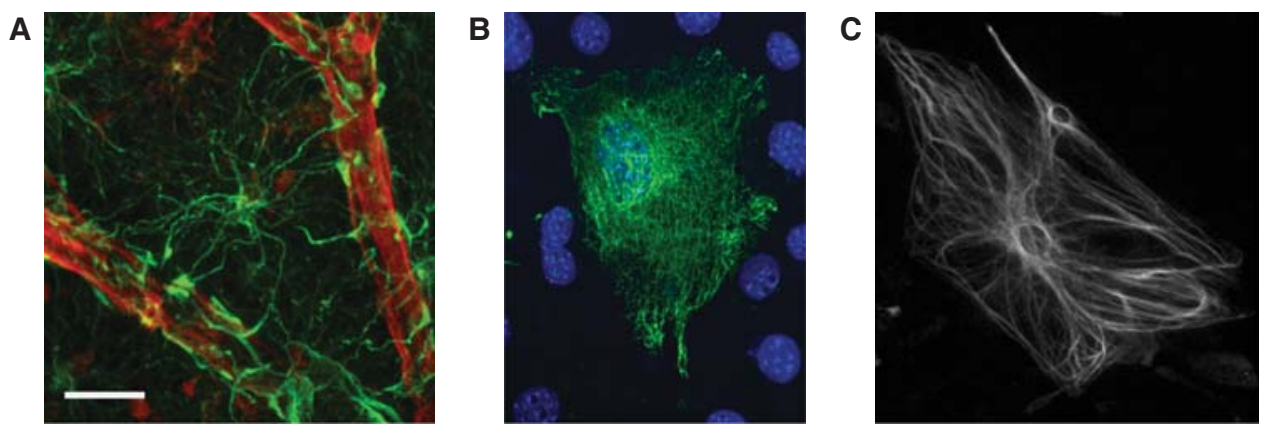

Figure 4. Expression of the intermediate filament (IF) protein glial fibrillary acidic protein (GFAP) in different cells. (A) GFAP (green) in astrocytes of the human frontal cortex; vimentin (red) stains the blood vessels. (B) Human GFAP $\alpha$ forms an IF network in vimentin-null mouse embryonic fibroblasts. ( $C$ ) Human GFAP $\alpha$ (white) integrates into the endogenous IF network of mouse primary astrocytes. Scale bar, $20 \mu \mathrm{m}(A), 5 \mu \mathrm{m}(B), 10 \mu \mathrm{m}(C)$.

cytes in the gray and white matter, in Müller glia in the retina, in Bergmann glia in the cerebellum, and in the adult neural stem cells in the subventricular zone (SVZ) and the subgranular zone (Middeldorp and Hol 2011). In addition, GFAP can also be expressed by Schwann cells in the peripheral nervous system, by mature glial cells in the gut, and in nonneural cells (Middeldorp and Hol 2011; Clairembault et al. 2014).

The precise function of GFAP is still not fully understood. GFAP has been implicated in cell migration, motility, and mitosis, which is relevant for the role of GFAP in the developing CNS and in glioma. Furthermore, GFAP contributes to the mechanical integrity of cells and is involved in cell signaling (Hol and Pekny 2015). GFAP-null mice are viable and can show changes in white matter instability emerging at old age or in neuronal plasticity (Middeldorp and Hol 2011). Expression profiling of GFAP-null astrocytes shows that several genes involved in interactions with the membrane or extracellular matrix are changed, supporting a role for GFAP in transducing signals from the exterior of the cell (Kamphuis et al. 2015). Overexpression of GFAP leads to formation of aggregates in astrocytes, resulting in a severe neurodegenerative phenotype, which is reminiscent of Alexander disease (Messing et al. 1998).

\subsubsection{GFAP Protein and GFAP Isoforms}

The GFAP gene consists of nine exons and, to date, 10 splice-isoforms of GFAP are known to be expressed in the mouse (Kamphuis et al. 2012) and human nervous system (Middeldorp and Hol 2011; Kamphuis et al. 2012; Kamphuis et al. 2014). In mouse brain, GFAP $\alpha, \beta, \gamma, \delta, \zeta, \kappa$, and $\Delta$ exon 7 are expressed, and, in human brain, GFAP $\alpha, \beta, \delta$, $\zeta, \kappa, \Delta 135, \Delta 164, \Delta$ exon6, and $\Delta$ exon 7 are expressed (Hol and Pekny 2015). The mRNAs and proteins of the isoforms are shown in Figure 5. The most abundantly expressed isoform is GFAP $\alpha$, and the majority of the published studies most likely describe GFAP $\alpha$ mRNA and protein expression.

GFAP $\alpha$ can self-assemble in a cell-free system (Perng et al. 2008), but, in astrocytes, the protein needs vimentin to coassemble into normal IFs (Eliasson et al. 1999). GFAP also forms heterodimers with the IF proteins nestin and synemin. The GFAP assembly in the cell cytoplasm is regulated by phosphorylation, and there is a constant exchange between soluble monomeric protein, short unitlength fragments, and the fully assembled GFAP network. Posttranslational modifications are phosphorylation, glycosylation, and ubiquitination (Middeldorp and Hol 2011; Hol and Pekny 2015), and the protein has a halflife of $\sim 1$ month (Price et al. 2010). The head, rod, and tail domains are important for proper assembly into filaments of thickness $10 \mathrm{~nm}$. The splice isoforms mainly vary in the carboxy-terminal protein sequences, resulting in GFAP proteins that are not able to form homodimers. Many interacting proteins have been identified, such as plectin, 14-3-3 proteins, $\alpha \mathrm{B}$-crystallin, Hsp27, presenilin, Lamp-2A, EF1 $\alpha$, other IFs, protein kinase $\mathrm{N}$, periplakin, and endoplakin (Nielsen and Jorgensen 2004; Middeldorp and Hol 2011; Hol and Pekny 2015). Recently, it was shown that the endocytosis of the Notch ligand jagged1 and Notch signaling from astrocytes to neurons is dependent on GFAP and vimentin (Wilhelmsson et al. 2012). It should be noted that most knowledge about the biological, biochemical, and biophysical properties of GFAP is based on experimental data obtained with the canonical GFAP $\alpha$ isoform. The effects of the recently discovered GFAP isoforms on GFAP assembly are only just beginning to be elucidated. The main isoforms studied are GFAP $\alpha$ and GFAP $\delta$. A high expression of GFAP $\delta$ leads to a collapse of the cellular IF network. Normally, the ratio of 


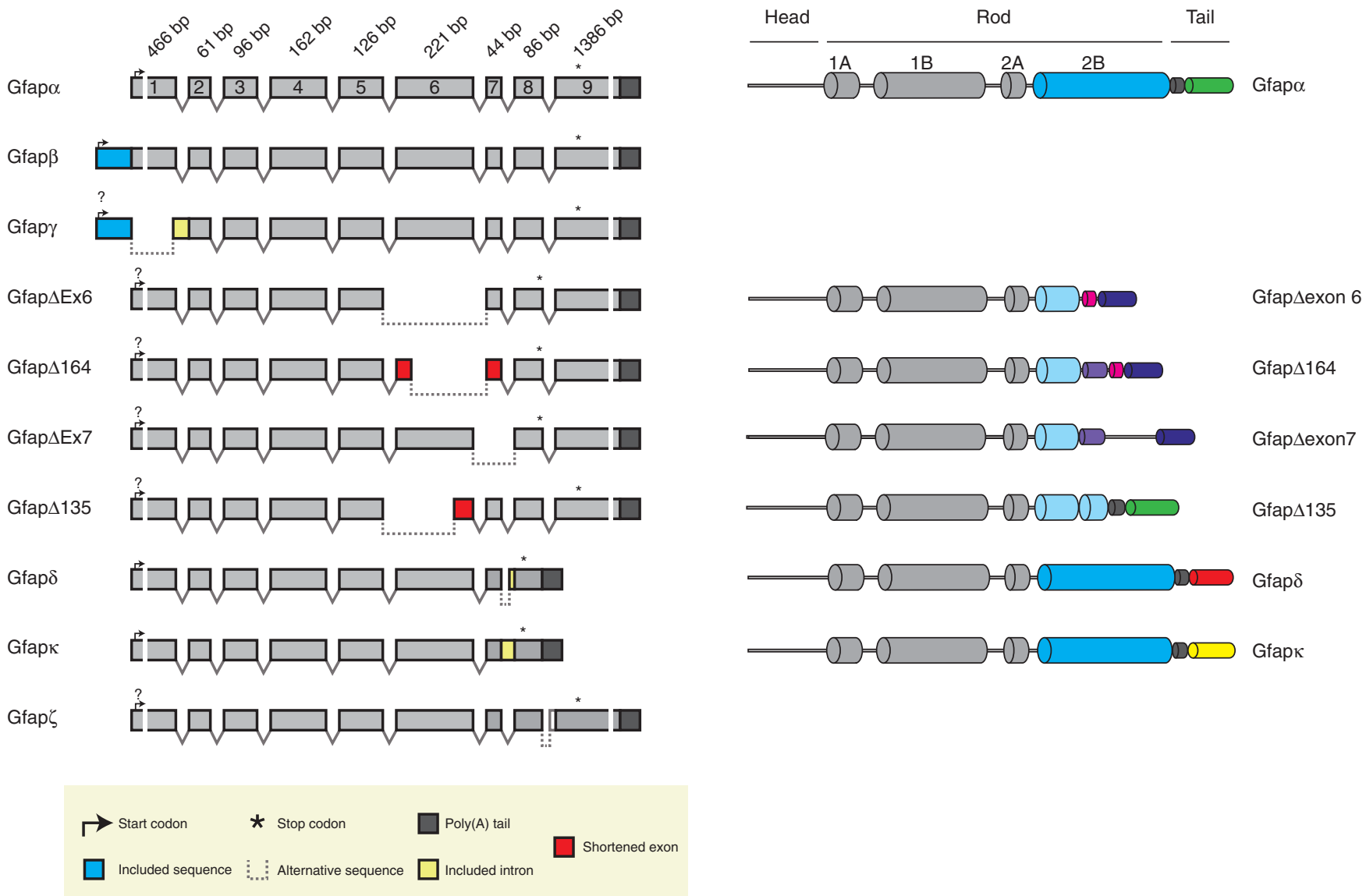

Figure 5. Schematic representation of the different mouse glial fibrillary acidic protein (GFAP) isoforms (modified from Kamphuis et al. 2012 and Hol and Pekny 2015). The scheme illustrates the differential splicing routes resulting in 10 different Gfap transcript isoforms (left). The size of the depicted exons is to scale except for exons 1 and 9, indicated by breaks. The sequences of Gfap $\alpha$ and Gfap $\delta$ have been determined by full-length cloning; for the other sequences, the exact $5^{\prime}$ sequence and the start codon are not known. The head, rod, and tail domains of the GFAP protein isoforms are indicated (right). The GFAP isoforms differ in the length of the rod domain and the sequence of the tail. The domains that are similar in each protein have the same shape and color. GFAP $\alpha$ and GFAP $\Delta 135$ have an identical carboxyl terminus (green), as do GFAP $\Delta$ exon $7, \Delta 164$, and $\Delta$ exon6 (dark purple). GFAP $\delta$ and GFAPк have unique carboxyl termini. No protein sequence for GFAP $\beta$, GFAP $\gamma$, and GFAP $\zeta$ can be deducted from the mRNA sequences. Please note that Gfap $\delta$ in some papers is designated as Gfap $\varepsilon$; however, these are exactly the same proteins.

GFAP $\delta /$ GFAP $\alpha$ is 10/90 (Roelofs et al. 2005). A change in this ratio by an increased expression of GFAP $\delta$ or a decrease in GFAP $\alpha$ results in a change in expression of laminin and plectin, affecting cell adhesion and migration (Moeton et al. 2014; Moeton et al. 2016).

In specific areas in the human brain, GFAP $\delta$ is predominantly expressed, such as in the SVZ astrocytes and subpial astrocytes (Roelofs et al. 2005). The SVZ GFAPS-immunopositive cells are the neural stem cells of the adult human brain (van Strien et al. 2014). Interestingly in human enteric glial cells, GFAPK is the main isoform (Clairembault et al. 2014). In contrast, in the mouse CNS, all astrocytes seem to express similar levels of the different splice iso- forms. Early studies showed that the stoichiometry between the different GFAP isoforms is of significance for proper GFAP IF formation and can change cell motility and expression of the extracellular matrix protein laminin and the cytoskeletal linker protein plectin (Roelofs et al. 2005; Perng et al. 2008; Kamphuis et al. 2012; Kamphuis et al. 2014; Moeton et al. 2014).

\subsection{GFAP in Brain Disease}

\subsubsection{GFAP Mutations and Alexander Disease}

De novo mutations in the GFAP gene cause Alexander disease, which is a progressive and fatal neurodegenerative 
disease. The disease is extremely rare, and it has been estimated to occur in 1 in 2.7 million people in Japan (Yoshida et al. 2011). Alexander patients suffer from seizures and severe cognitive disabilities in the more aggressive juvenile form and from problems with coordination, speech, and swallowing in the late-onset cases (Quinlan et al. 2007). The mutations are scattered over the full length of the GFAP protein, with two hotspots in the rod domain: R79 and R239. Most of the mutations result in a coding change of one amino acid or in a deletion or insertion of one or a few amino acids. Recently, frameshift mutations and an intronic splice-site mutation have been described (Flint et al. 2012). These mutations all result in abnormal IF networks in the cell and a propensity for the GFAP protein to form aggregates. The consequences for GFAP isoform expression are not known yet. The neuropathological hallmark of this disease is the presence of Rosental fibers in astrocytes, which are aggregates of ubiquitinated GFAP proteins, $\alpha$ B-crystallin, and HSP27 (Quinlan et al. 2007). Such aggregates can also be induced by an overexpression of wild-type GFAP. How the changes in IF properties and the GFAP aggregates affect astrocyte function is not known.

Astrocytes are important players in neurodevelopment and synaptogenesis. In the adult brain, they control the level of neurotransmitters, water, and ions and thus are essential for optimal neuronal communication. More importantly, astrocytes are part of the tripartite synapse and are an active player in synaptic transmission. Therefore, dysfunctional astrocytes arising from mutations in GFAP can cause a neurodevelopmental phenotype or affect neuronal communication in the adult brain (Hol and Pekny 2015).

\subsubsection{GFAP in Reactive Gliosis}

Astrocytes become reactive during a neurological disease and upon brain damage. An increase in GFAP is observed in brains in patients suffering from neurodegenerative diseases (Alzheimer's, Parkinson's, and Huntington's), acute brain injuries (traumatic brain injury, ischemic and hemorrhagic stroke), epilepsy, and lower-grade astrocytoma. A characteristic of reactive gliosis is an increase in astrocytic IF proteins, GFAP, vimentin, synemin, and nestin. This leads to thicker IF bundles in the astrocytic processes (Hol and Pekny 2015). Reactive gliosis has many different faces-it can be a slow but chronic response such as in Alzheimer's disease, or it can be acute such as in brain trauma. In both instances, GFAP is up-regulated, but the exact changes in the IF network and the contribution of other IFs and the GFAP isoforms need further elucidation.

In Alzheimer's mouse models and human Alzheimer's brain tissue, many of the GFAP isoforms are up-regulated (Kamphuis et al. 2012; Kamphuis et al. 2014). In the human brain, the number of astrocytes expressing a frameshifted GFAP variant $\left(\mathrm{GFAP}^{+1}\right)$ is highly correlated with Alzheimer's pathology. As these cells are very sparse, it has been difficult to determine which mRNA isoform leads to this variant. Three different mRNAs can code for this variant, GFAP $\Delta 164, \Delta$ exon6, and $\Delta$ exon 7 , and all of these are expressed in Alzheimer's brains (at a low level) and show a trend to be up-regulated with increased pathology (Kamphuis et al. 2014). Changes in the IF network are likely to contribute to functional changes in reactive astrocytes. Several studies have been performed on mice with a deficiency in GFAP alone or in GFAP and vimentin (Pekny 2001). These experiments revealed that a loss of the IF network leads to a weakened reactive gliosis response, a larger area of brain damage and synaptic loss after trauma, and less resistance to mechanical stress (Pekny 2001; Hol and Pekny 2015). A recent study revealed changes in the transcriptome of reactive astrocytes with different IF networks acutely isolated from Alzheimer's mice. Astrocytes with a deficiency in GFAP or GFAP-vimentin showed a more pronounced increase in pro- and anti-inflammatory genes and a rescue of the decrease in the expression of neuronal support genes that occurs in Alzheimer's mice with a normal IF network (Kamphuis et al. 2015). More research is needed to link these changes in gene expression to functional changes.

\subsubsection{GFAP in Brain Tumors}

Astrocytic brain tumors (glioma) and astrocytoma cell lines express four IF proteins: GFAP, vimentin, synemin, and nestin (Hol and Pekny 2015). The expression of nestin and vimentin indicates an undifferentiated, more stemcell-like state of these cells. Astrocytoma cells also express the GFAP isoforms GFAP $\alpha$ and GFAP $\delta$. In these cells, GFAP splicing is tightly regulated, and a change in the splice-pattern leads to a collapse of the IF network (Kanski et al. 2014), which is reminiscent of Rosenthal fibers that can occur in astrocytoma. A modulation of the IF network leads to a change in morphology, focal adhesion size, and, in some instances, motility of astrocytoma cells, and this coincides with a change in integrin, laminin, and plectin expression (Moeton et al. 2014, Moeton et al. 2016). The exact IF composition of a glioma is not well characterized, but it does appear in general that the GFAP levels decline with a higher glioma grade and that the markers for immature glia (nestin and vimentin) increase. However, GFAPס, a marker for adult neural stem cells, has been associated with tumor grade (Brehar et al. 2015). This likely reflects an increase in the GFAP $\delta / \alpha$ ratio in higher-grade astrocytoma. In conclusion, both the IF composition and the stoichiometry of the GFAP splice variants 
seem to be important determinants of the final cellular behavior.

\section{PERIPHERIN}

\subsection{Expression in the Developing and Adult Nervous System}

Peripherin is a 58-kDa IF protein first described in 1983 (Portier et al. 1983) and cloned in 1988 (Leonard et al. 1988). The protein is highly homologous to the other type III IFs and can assemble by itself in a filamentous network in SW13 cells (Zhao and Liem 2016). The expression of peripherin is restricted to neurons of the peripheral nervous system and the CNS that have peripheral axons. In the developing CNS, peripherin is already clearly expressed at the 34-somite stage (E17-E18) but not yet at the 25somite (E12.5) rat embryo. Peripherin immunoreactivity is restricted to autonomic and sensory neurons and spinal motor neurons during development (Escurat et al. 1990) and in the adult brain (Brody et al. 1989). The peripherin protein interacts with neurofilament subunits (Parysek et al. 1991). Four main isoforms of peripherin are expressed in the mouse: the $58-\mathrm{kDa}$ variant is the dominant isoform (Per 58), and differential splicing leads to Per 45, Per 56, and Per 61 (Landon et al. 1989; McLean et al. 2008). Per 45 is the result of an inframe downstream initiation codon, Per 56 is an out-of-frame variant that is the result of a cryptic splice site in exon 9, and Per 61 contains an additional 32 amino acids within the rod region caused by retention of intron 4. Per 61 cannot occur in human as the intron 4 retention in this case will lead to a truncated frameshifted protein of $32 \mathrm{kDa}$. However, in human, an even shorter peripherin is expressed, Per 28, which is the result of an intron 3 and intron 4 retention, leading to a stop codon in intron 3 (Xiao et al. 2008). Per 28 and Per 61 cannot selfassemble into filaments in SW13 cells and form aggregates (Zhao and Liem 2016).

The high expression level of peripherin during development and the increase of the level of peripherin on the outgrowth of axons (Xiao et al. 2006) suggest a role for peripherin in axonal guidance and regeneration. However, the exact function of peripherin and its isoforms is still elusive. Peripherin-deficient mice do not display a clear phenotype, but the levels of the type IV $\alpha$-internexin increased, and a significant reduction of unmyelinated sensory axons was observed (Lariviere et al. 2002). These data suggest a role for peripherin in the development of a subset of sensory neurons. Recently, Per 61 interactors have been identified, and the interaction with synaptosomal-associated protein 25 (SNAP 25) interacting protein (SIP30) suggests a role for peripherin in vesicle trafficking (Gentil et al. 2014).

\subsection{Role in Brain Disease}

Peripherin is up-regulated on injury of axons (Wong and Oblinger 1990). It is suggested that an up-regulation of peripherin is a regenerative response, but complex posttranslational processing can push the regenerative response toward a pathological process (McLean et al. 2010). By analogy with GFAP, an overexpression of peripherin is detrimental for cells as it induces neurodegeneration and eventually neuronal death (Liem and Messing 2009). Peripherin neuropathological inclusions, which also contain neurofilaments, have been observed in motor neurons of sporadic and familial amyotrophic lateral sclerosis (ALS) patients (Xiao et al. 2006). ALS is a devastating motor neuron disease, characterized by a loss of motor neurons in the cortex, brain stem, and spinal cord. Peripherin expression is increased in ALS cases, potentially contributing to an expansion in the number of intraneuronal aggregates. Furthermore, a frameshift deletion in the gene encoding peripherin has been associated with ALS (LepinouxChambaud and Eyer 2013).

Peripherin splice variants have been implicated in ALS. In the SOD1G37R mouse model of ALS, the expression of the mouse-specific splice variant Per 61 is induced. This variant is not observed in controls. The expression of this variant leads to peripherin and neurofilament inclusions and causes neurotoxicity in vitro (Robertson et al. 2003). In human ALS cases, a novel peripherin variant was discovered, Per 28, which is present in motor neuron inclusions and is only expressed in ALS cases (Xiao et al. 2008). Per 28 expression in motor neurons induces inclusion bodies. Peripherin isoform expression has been profiled in the nervous tissue of mouse models for trauma (sciatic nerve crush), stroke (middle cerebral artery occlusion), and ALS (SOD-1 ${ }^{\text {G93A }}$ ), and in human control and ALS spinal cords. These studies showed specific peripherin biochemical signatures for each condition (McLean et al. 2010).

\section{VIMENTIN}

\subsection{Vimentin as a Potential Regulator of Growth and Differentiation}

Vimentin was the first member of the type III IF protein coding genes to be cloned (Capetanaki et al. 1983; Zehner and Paterson 1983). Vimentin is mainly expressed in undifferentiated and proliferative cells of mesenchymal origin and, on differentiation, is replaced by the corresponding cell type-specific IF protein (Tapscott et al. 1981; Capetanaki et al. 1984; Olson and Capetanaki 1989). Vimentin is also expressed in fully differentiated cells, such as blood and lens cells. Its expression is regulated by growth factors, and it belongs to the early-response-competence gene fam- 
ily (Rittling et al. 1985; Ferrari et al. 1986). Several investigations have suggested the involvement of vimentin in growth and differentiation of different systems, including muscle (Olson and Capetanaki 1989), lens (Capetanaki et al. 1989; Mou et al. 2010), and osteoblasts (Lian et al. 2009). In all these cases, overexpression of vimentin, ectopic or owing to the absence of its repressor HSF4 (Mou et al. 2010), inhibits differentiation. The mechanism of this inhibition has been further revealed in the case of osteoblasts in which differentiation is suppressed through direct binding of the vimentin first leucine zipper (LZ) domain to the osteoblast-specific LZ-containing transcription factor ATF-4 (Lian et al. 2009). This is in agreement with the previously reported structural similarities between the leucine-rich domains of vimentin and the LZ motif of several other LZ-containing transcription regulators, including fos, jun, and cAMP response element-binding protein (CREB) (Capetanaki et al. 1990), which have allowed the prediction of potential interactions of these proteins with vimentin through their leucine-rich amphipathic helices.

All the above observations are also consistent with the fact that vimentin is expressed in almost all cancer cells, and its expression levels have been linked to metastasis and poor prognosis (see, also, the review by Cheng and Eriksson 2016). The common growth-regulated expression and the above-discussed intriguing structural similarity $(50 \%-$ $70 \%$ ) of vimentin with the nuclear proto-oncogene products c-fos, its related antigen fra-1, c-jun, as well as the amino-terminal activation domain tpr of the oncogenic raf (Capetanaki et al. 1990) and the v-mos oncogene product (Bai et al. 1993) have long since raised the question of a potentially active role of vimentin in tumorigenesis, perhaps by interactions that could influence their function, along with its general role as a brake on differentiation. Of further interest is the finding that overexpression of cmos in the lens of transgenic mice inhibits lens cell differentiation in a fashion similar to that of vimentin (Khillan et al. 1987). Most importantly, vimentin seems to be a central molecule in the epithelial-mesenchymal transition (EMT), known for its crucial role in malignant transformation and metastatic spread (for review, see Ivaska 2011 and Kidd et al. 2014).

\subsection{Vimentin IFs as a Signaling and Trafficking Facilitator Scaffold}

Studies with the vimentin-null mice (Colucci-Guyon et al. 1994) showed, initially, a mild phenotype but when extended later showed, as initially expected, several defects, including compromised motility and directional migration that affected wound healing (Eckes et al. 2000), mechanotransduction of shear stress (Henrion et al. 1997) and lym- phocyte adhesion, and transcellular migration (Nieminen et al. 2006). These functions of vimentin are reviewed by Cheng and Eriksson (2016).

The function of vimentin as a cell-signaling scaffold/ organizer has been amply shown (Ivaska et al. 2007; Hyder et al. 2008; Eriksson et al. 2009), and its dynamic assembly/ disassembly properties through posttranslational modifications by phosphorylation and glycosylation have been linked to the regulatory function of vimentin in the signaling of its corresponding kinase modifiers.

Vimentin has also been implicated in the protein kinase $\mathrm{C}$ epsilon (PKC $\epsilon$ )-mediated trafficking of integrins to the plasma membrane and, thus, is considered an important organizer of integrins (Ivaska et al. 2005). In addition, vimentin has been linked to membrane trafficking through adaptor protein AP-3 association (Styers et al. 2004). Similar to desmin described above, vimentin and peripherin are also important for lysosome (Styers et al. 2005) and lysosome-related organelle behavior (Chang et al. 2009) and, potentially through proper BLOC-1/AP-3 coexistence, they support proper cellular trafficking. The type III IF protein, GFAP, has also been linked to lysosomes and, more specifically, was found to associate with lysosome-associated membrane protein type $2 \mathrm{~A}$ (LAMP-2A) and modulate chaperone-mediated autophagy (Bandyopadhyay et al. 2010). Furthermore, the formation of the autophagosome intermediate organelle, which converges with lysosomes during the autophagic process, requires intact cytokeratin and vimentin IFs (Holen et al. 1992; Blankson et al. 1995) Vimentin also interacts with the Golgi complex (Gao et al. 2002) and has been linked to maturation of glycosphingolipids (Gillard et al. 1994) and steroidogenesis (Shen et al. 2012). More recent studies have shown the importance of vimentin (and GFAP, as discussed above) in endocytosis of the Notch ligand Jagged1 in astrocytes (Wilhelmsson et al. 2012). Furthermore, vimentin, like desmin, is linked to mitochondrial behavior and function (Chernoivanenko et al. 2015). Additionally, it has been established that vimentin intermediate filaments can establish mitotic polarity and mediate the asymmetric partitioning of damaged proteins (Ogrodnik et al. 2014). Finally, it has recently been shown that vimentin interacts with components of the NLRP3 inflammasome and regulates its activation (dos Santos et al. 2015).

\section{CONCLUSION}

All types of IF proteins, including type III, form versatile IF networks that can interact with different cellular components and cell-signaling molecules. These interactions facilitate the proper integration of cell type-specific structure and function, and play a central role in the regulation of the 
corresponding tissue development and homeostasis. This IF-dependent integration includes mechanochemical signaling, interaction with the extracellular matrix, organelle cross talk, and transcriptional processes, with important consequences for the regulation of differentiation, metabolism, and cell survival. Dysregulation of this structurefunction integration leads to chronic disease. Therefore, future studies must focus on further understanding of the molecular mechanisms underlying the interactions of IF proteins with different organelles, cellular components, and signaling molecules, and how its disturbance influences mechanochemical coupling, both in signaling and trafficking processes, as well as in cellular organelle biogenesis and cross talk. Given that modulation of the expression level of IF proteins and the exact composition of the different IFs and their isoforms in the network are all factors that are involved in cell type-specific functional changes, further understanding of the generation of this complexity and its importance is mandatory.

\section{ACKNOWLEDGMENTS}

We thank Ismini Klookina for Figure 2I, George Ksistris for his artwork for Figure 3, Nicholas Flytzanis for reading the review, and Roland van Dijk and Martina Moeton for sharing their images for Figure 4. The human brain tissue in Figure 4 was obtained from the Netherlands Brain Bank. The authors' work reviewed here was supported by ESPA 2007-2013 grants from the Greek General Secretariat of Research and Development/Ministerium of Education (PENED 01ED371, EPAN YB-22, PEP ATT-39, and ESPA 09SYN-21-965), grant of Excellence II/ ARISTEIA II 5342, and the U.S. National Institutes of Health RO1 AR39617 to Y.C., and COST (Cooperation of Science and Technology) BM (Biomedicine and Molecular Sciences) 1002, NWO (Nederlandse Organisatie voor Wetenschappelijk Onderzoek), ISAO (Internationale Stichting Alzheimer Onderzoek). FOM (Stichting voor Fundamenteel Onderzoek der Materie), Hersenstichting Nederland, Stichting Parkinson Fonds, and Dorpmans-Wigmans Stichting to E.M.H.

\section{REFERENCES}

* Reference is also in this collection.

* Adam SA. 2016. The nucleoskeleton. Cold Spring Harb Perspect Biol doi: $10.1101 /$ cshperspect.a023556.

Allen RE, Rankin LL, Greene EA, Boxhorn LK, Johnson SE, Taylor RG, Pierce PR. 1991. Desmin is present in proliferating rat muscle satellite cells but not in bovine muscle satellite cells. J Cell Physiol 149: 525-535.

Ansseau E, Eidahl JO, Lancelot C, Tassin A, Matteotti C, Yip C, Liu J, Leroy B, Hubeau C, Gerbaux C, et al.. 2016. Homologous transcrip- tion factors DUX4 and DUX4c associate with cytoplasmic proteins during muscle differentiation. PLoS ONE 11: e0146893.

Bai W, Arlinghaus RB, Singh B. 1993. Association of v-Mos with soluble vimentin in vitro and in transformed cells. Oncogene 8: 2207-2212.

Bandyopadhyay U, Sridhar S, Kaushik S, Kiffin R, Cuervo AM. 2010. Identification of regulators of chaperone-mediated autophagy. Mol Cell 39: 535-547.

Bang ML, Gregorio C, Labeit S. 2002. Molecular dissection of the interaction of desmin with the C-terminal region of nebulin. J Struct Biol 137: 119-127.

Bennardini F, Wrzosek A, Chiesi M. 1992. $\alpha$ B-crystallin in cardiac tissue. Association with actin and desmin filaments. Circ Res 71: 288-294.

Benson MA, Tinsley CL, Blake DJ. 2004. Myospryn is a novel binding partner for dysbindin in muscle. J Biol Chem 279: 10450-10458.

Blankson H, Holen I, Seglen PO. 1995. Disruption of the cytokeratin cytoskeleton and inhibition of hepatocytic autophagy by okadaic acid. Exp Cell Res 218: 522-530.

Brehar FM, Arsene D, Brinduse LA, Gorgan MR. 2015. Immunohistochemical analysis of GFAP- $\delta$ and nestin in cerebral astrocytomas. Brain Tumor Pathol 32: 90-98.

Brody BA, Ley CA, Parysek LM. 1989. Selective distribution of the $57 \mathrm{kDa}$ neural intermediate filament protein in the rat CNS. J Neurosci 9: 2391-2401.

Brownlees J, Ackerley S, Grierson AJ, Jacobsen NJ, Shea K, Anderton BH, Leigh PN, Shaw CE, Miller CC. 2002. Charcot-Marie-Tooth disease neurofilament mutations disrupt neurofilament assembly and axonal transport. Hum Mol Genet 11: 2837-2844.

Buckingham ME, Lyons GE, Ott MO, Sassoon DA. 1992. Myogenesis in the mouse. Ciba Found Symp 165: 111-124.

Capetanaki Y. 2002. Desmin cytoskeleton: A potential regulator of muscle mitochondrial behavior and function. Trends Cardiovasc Med 12: 339-348.

Capetanaki YG, Ngai J, Flytzanis CN, Lazarides E. 1983. Tissue-specific expression of two mRNA species transcribed from a single vimentin gene. Cell 35: 411-420.

Capetanaki YG, Ngai J, Lazarides E. 1984. Characterization and regulation in the expression of a gene coding for the intermediate filament protein desmin. Proc Natl Acad Sci 81: 6909-6913.

Capetanaki Y, Smith S, Heath JP. 1989. Overexpression of the vimentin gene in transgenic mice inhibits normal lens cell differentiation. J Cell Biol 109: 1653-1664.

Capetanaki Y, Kuisk I, Rothblum K, Starnes S. 1990. Mouse vimentin: Structural relationship to fos, jun, CREB and tpr. Oncogene 5: 645655.

Capetanaki Y, Milner DJ, Weitzer G. 1997. Desmin in muscle formation and maintenance: Knockouts and consequences. Cell Struct Funct 22: $103-116$.

Capetanaki Y, Bloch RJ, Kouloumenta A, Mavroidis M, Psarras S. 2007. Muscle intermediate filaments and their links to membranes and membranous organelles. Exp Cell Res 313: 2063-2076.

Capetanaki Y, Papathanasiou S, Diokmetzidou A, Vatsellas G, Tsikitis M. 2015. Desmin related disease: A matter of cell survival failure. Curr Opin Cell Biol 32C: 113-120.

Cerqua C, Anesti V, Pyakurel A, Liu D, Naon D, Wiche G, Baffa R, Dimmer KS, Scorrano L. 2010. Trichoplein/mitostatin regulates endoplasmic reticulum-mitochondria juxtaposition. EMBO Rep 11: $854-860$

Cetin N, Balci-Hayta B, Gundesli H, Korkusuz P, Purali N, Talim B, Tan E, Selcen D, Erdem-Ozdamar S, Dincer P. 2013. A novel desmin mutation leading to autosomal recessive limb-girdle muscular dystrophy: Distinct histopathological outcomes compared with desminopathies. $J$ Med Genet 50: 437-443.

Chang L, Barlan K, Chou YH, Grin B, Lakonishok M, Serpinskaya AS, Shumaker DK, Herrmann H, Gelfand VI, Goldman RD. 2009. The dynamic properties of intermediate filaments during organelle transport. J Cell Sci 122: 2914-2923. 
* Cheng F, Eriksson JE. 2016. Intermediate filaments and the regulation of cell motility during regeneration and wound healing. Cold Spring Harb Perspect Biol doi: 10.1101/cshperspect.a022046.

Chernoivanenko IS, Matveeva EA, Gelfand VI, Goldman RD, Minin AA. 2015. Mitochondrial membrane potential is regulated by vimentin intermediate filaments. FASEB J 29: 820-827.

Clairembault T, Kamphuis W, Leclair-Visonneau L, Rolli-Derkinderen M, Coron E, Neunlist M, Hol EM, Derkinderen P. 2014. Enteric GFAP expression and phosphorylation in Parkinson's disease. J Neurochem 130: $805-815$.

Clemen CS, Herrmann H, Strelkov SV, Schroder R. 2013. Desminopathies: Pathology and mechanisms. Acta Neuropathol 125: 47-75.

Colucci-Guyon E, Portier MM, Dunia I, Paulin D, Pournin S, Babinet C. 1994. Mice lacking vimentin develop and reproduce without an obvious phenotype. Cell 79: 679-694.

Conover GM, Gregorio CC. 2011. The desmin coil 1B mutation K190A impairs nebulin Z-disc assembly and destabilizes actin thin filaments. J Cell Sci 124: 3464-3476.

Diokmetzidou A, Soumaka E, Kloukina I, Tsikitis M, Makridakis M, Varela A, Davos CH, Georgopoulos S, Anesti A, Vlachou A, et al. 2016. Desmin and $\alpha \mathrm{B}$-crystallin interplay in maintenance of mitochondrial homeostasis and cardiomyocyte survival. J Cell Sci 129: 3705-3720.

dos Santos G, Rogel MR, Baker MA, Troken JR, Urich D, Morales-Nebreda L, Sennello JA, Kutuzov MA, Sitikov A, Davis JM, et al. 2015. Vimentin regulates activation of the NLRP3 inflammasome. Nat Commun 6: 6574-6586.

Eckes B, Colucci-Guyon E, Smola H, Nodder S, Babinet C, Krieg T, Martin P. 2000. Impaired wound healing in embryonic and adult mice lacking vimentin. J Cell Sci 113: 2455-2462.

Eliasson C, Sahlgren C, Berthold CH, Stakeberg J, Celis JE, Betsholtz C, Eriksson JE, Pekny M. 1999. Intermediate filament protein partnership in astrocytes. J Biol Chem 274: 23996-24006.

Eng LF, Vanderhaeghen JJ, Bignami A, Gerstl B. 1971. An acidic protein isolated from fibrous astrocytes. Brain Res 28: 351-354.

Eng LF, Ghirnikar RS, Lee YL. 2000. Glial fibrillary acidic protein: GFAP-thirty-one years (1969-2000). Neurochem Res 25: 14391451.

Eriksson JE, Dechat T, Grin B, Helfand B, Mendez M, Pallari HM, Goldman RD. 2009. Introducing intermediate filaments: From discovery to disease. J Clin Invest 119: 1763-1771.

Escurat M, Djabali K, Gumpel M, Gros F, Portier MM. 1990. Differential expression of two neuronal intermediate-filament proteins, peripherin and the low-molecular-mass neurofilament protein (NF-L), during the development of the rat. J Neurosci 10: 764-784.

Fekete E, Timmermans JP, Resch BA, Scheuermann DW. 1999. Different distribution of S-100 protein and glial fibrillary acidic protein (GFAP) immunoreactive cells and their relations with nitrergic neurons in the human fetal small intestine. Histol Histopathol 14: 785790.

Ferrari S, Battini R, Kaczmarek L, Rittling S, Calabretta B, de Riel JK, Philiponis V, Wei JF, Baserga R. 1986. Coding sequence and growth regulation of the human vimentin gene. Mol Cell Biol 6: 3614-3620.

Flint D, Li R, Webster LS, Naidu S, Kolodny E, Percy A, van der Knaap M, Powers JM, Mantovani JF, Ekstein J, et al. 2012. Splice site, frameshift, and chimeric GFAP mutations in Alexander disease. Hum Mutat 33: $1141-1148$.

Fountoulakis M, Soumaka E, Rapti K, Mavroidis M, Tsangaris G, Maris A, Weisleder N, Capetanaki Y. 2005. Alterations in the heart mitochondrial proteome in a desmin null heart failure model. J Mol Cell Cardiol 38: 461-474.

Fox IJ, Paucar AA, Nakano I, Mottahedeh J, Dougherty JD, Kornblum HI. 2004. Developmental expression of glial fibrillary acidic protein mRNA in mouse forebrain germinal zones-Implications for stem cell biology. Brain Res Dev Brain Res 153: 121-125.
Frock RL, Kudlow BA, Evans AM, Jameson SA, Hauschka SD, Kennedy BK. 2006. Lamin A/C and emerin are critical for skeletal muscle satellite cell differentiation. Genes Dev 20: 486-500.

Fuchs C, Gawlas S, Heher P, Nikouli S, Paar H, Ivankovic M, Schultheis M, Klammer J, Gottschamel T, Capetanaki Y, et al. 2016. Desmin enters the nucleus of cardiac stem cells and modulates Nkx2.5 expression by participating in transcription factor complexes that interact with the $n k x 2.5$ gene. BiolOpen 5: 140-153.

Fujii T, Takagi H, Arimoto M, Ootani H, Ueeda T. 2000. Bundle formation of smooth muscle desmin intermediate filaments by calponin and its binding site on the desmin molecule. J Biochem 127: 457-465.

Gao YS, Vrielink A, MacKenzie R, Sztul E. 2002. A novel type of regulation of the vimentin intermediate filament cytoskeleton by a Golgi protein. Eur J Cell Biol 81: 391-401.

Garcia-Verdugo I, Synguelakis M, Degrouard J, Franco CA, Valot B, Zivy M, Chaby R, Tanfin Z. 2008. Interaction of surfactant protein A with the intermediate filaments desmin and vimentin. Biochemistry 47: 5127-5138.

Gentil BJ, McLean JR, Xiao S, Zhao B, Durham HD, Robertson J. 2014. A two-hybrid screen identifies an unconventional role for the intermediate filament peripherin in regulating the subcellular distribution of the SNAP25-interacting protein, SIP30. J Neurochem 131: 588-601.

Georgatos SD, Blobel G. 1987. Lamin B constitutes an intermediate filament attachment site at the nuclear envelope. J Cell Biol 105: $117-125$.

Gillard BK, Thurmon LT, Harrell RG, Capetanaki Y, Saito M, Yu RK, Marcus DM. 1994. Biosynthesis of glycosphingolipids is reduced in the absence of a vimentin intermediate filament network. J Cell Sci 107: 3545-3555.

Goldfarb LG, Dalakas MC. 2009. Tragedy in a heartbeat: Malfunctioning desmin causes skeletal and cardiac muscle disease. J Clin Invest 119: $1806-1813$.

Henrion D, Terzi F, Matrougui K, Duriez M, Boulanger CM, ColucciGuyon E, Babinet C, Briand P, Friedlander G, Poitevin P, et al. 1997. Impaired flow-induced dilation in mesenteric resistance arteries from mice lacking vimentin. J Clin Invest 100: 2909-2914.

Hernandez DA, Wilcox CM, Dunina-Barkovskaya L, Wedig T, Capetanaki Y, Herrmann H, Conover GM. 2016. Nebulette is a powerful cytolinker organizing desmin and actin in mouse hearts. Mol Biol Cell pii: mbc.E16-04-0237.

* Herrmann H, Aebi U. 2016. Intermediate filaments: Structure and assembly. Cold Spring Harb Perspect Biol 8: a018242.

Hnia K, Tronchere H, Tomczak KK, Amoasii L, Schultz P, Beggs AH, Payrastre B, Mandel JL, Laporte J. 2011. Myotubularin controls desmin intermediate filament architecture and mitochondrial dynamics in human and mouse skeletal muscle. J Clin Invest 121: $70-85$.

Hofner M, Hollrigl A, Puz S, Stary M, Weitzer G. 2007. Desmin stimulates differentiation of cardiomyocytes and up-regulation of brachyury and nkx2.5. Differentiation 75: 605-615.

Hol EM, Pekny M. 2015. Glial fibrillary acidic protein (GFAP) and the astrocyte intermediate filament system in diseases of the central nervous system. Curr Opin Cell Biol 32C: 121-130.

Holen I, Gordon PB, Seglen PO. 1992. Protein kinase-dependent effects of okadaic acid on hepatocytic autophagy and cytoskeletal integrity. Biochem J 284(Pt 3): 633-636.

Hollrigl A, Puz S, Al-Dubai H, Kim JU, Capetanaki Y, Weitzer G. 2002. Amino-terminally truncated desmin rescues fusion of $\mathrm{des}^{-/-}$myoblasts but negatively affects cardiomyogenesis and smooth muscle development. FEBS Lett 523: 229-233.

Hollrigl A, Hofner M, Stary M, Weitzer G. 2007. Differentiation of cardiomyocytes requires functional serine residues within the aminoterminal domain of desmin. Differentiation 75: 616-626.

Hyder CL, Pallari HM, Kochin V, Eriksson JE. 2008. Providing cellular signposts-Post-translational modifications of intermediate filaments. FEBS Lett 582: 2140-2148. 
Ivaska J. 2011. Vimentin: Central hub in EMT induction? Small GTPases 2: $51-53$

Ivaska J, Vuoriluoto K, Huovinen T, Izawa I, Inagaki M, Parker PJ. 2005. PKC $\varepsilon$-mediated phosphorylation of vimentin controls integrin recycling and motility. EMBO J 24: 3834-3845.

Ivaska J, Pallari HM, Nevo J, Eriksson JE. 2007. Novel functions of vimentin in cell adhesion, migration, and signaling. Exp Cell Res 313: 2050-2062.

Kamphuis W, Mamber C, Moeton M, Kooijman L, Sluijs JA, Jansen AH, Verveer M, de Groot LR, Smith VD, Rangarajan S, et al. 2012. GFAP isoforms in adult mouse brain with a focus on neurogenic astrocytes and reactive astrogliosis in mouse models of Alzheimer disease. PLoS ONE 7: e42823.

Kamphuis W, Middeldorp J, Kooijman L, Sluijs JA, Kooi EJ, Moeton M, Freriks M, Mizee MR, Hol EM. 2014. Glial fibrillary acidic protein isoform expression in plaque related astrogliosis in Alzheimer's disease. Neurobiol Aging 35: 492-510.

Kamphuis W, Kooijman L, Orre M, Stassen O, Pekny M, Hol EM. 2015. GFAP and vimentin deficiency alters gene expression in astrocytes and microglia in wild-type mice and changes the transcriptional response of reactive glia in mouse model for Alzheimer's disease. Glia 63:10361156.

Kanski R, Sneeboer MA, van Bodegraven EJ, Sluijs JA, Kropff W, Vermunt MW, Creyghton MP, De FL, Vescovi A, Aronica E, et al. 2014. Histone acetylation in astrocytes suppresses GFAP and stimulates a reorganization of the intermediate filament network. J Cell Sci 127: 43684380.

Kartenbeck J, Franke WW, Moser JG, Stoffels U. 1983. Specific attachment of desmin filaments to desmosomal plaques in cardiac myocytes. EMBO J 2: 735-742.

Kay L, Li Z, Mericskay M, Olivares J, Tranqui L, Fontaine E, Tiivel T, Sikk P, Kaambre T, Samuel JL, et al. 1997. Study of regulation of mitochondrial respiration in vivo. An analysis of influence of ADP diffusion and possible role of cytoskeleton. Biochim Biophys Acta 1322: $41-59$.

Khillan JS, Oskarsson MK, Propst F, Kuwabara T, Vande Woude GF, Westphal H. 1987. Defects in lens fiber differentiation are linked to c-mos overexpression in transgenic mice. Genes Dev 1: 13271335.

Kidd ME, Shumaker DK, Ridge KM. 2014. The role of vimentin intermediate filaments in the progression of lung cancer. Am J Respir Cell Mol Biol 50: 1-6.

Kielbasa OM, Reynolds JG, Wu CL, Snyder CM, Cho MY, Weiler H, Kandarian S, Naya FJ. 2011. Myospryn is a calcineurin-interacting protein that negatively modulates slow-fiber-type transformation and skeletal muscle regeneration. FASEB J 25: 2276-2286.

Konieczny P, Fuchs P, Reipert S, Kunz WS, Zeold A, Fischer I, Paulin D, Schroder R, Wiche G. 2008. Myofiber integrity depends on desmin network targeting to Z-disks and costameres via distinct plectin isoforms. J Cell Biol 181: 667-681.

Kouloumenta A, Mavroidis M, Capetanaki Y. 2007. Proper perinuclear localization of the TRIM-like protein myospryn requires its binding partner desmin. J Biol Chem 282: 35211-35221.

Kuisk IR, Li H, Tran D, Capetanaki Y. 1996. A single MEF2 site governs desmin transcription in both heart and skeletal muscle during mouse embryogenesis. Dev Biol 174: 1-13.

Landon F, Lemonnier M, Benarous R, Huc C, Fiszman M, Gros F, Portier MM. 1989. Multiple mRNAs encode peripherin, a neuronal intermediate filament protein. EMBO J 8: 1719-1726.

Langley RC Jr, Cohen CM. 1986. Association of spectrin with desmin intermediate filaments. J Cell Biochem 30: 101-109.

Lapouge K, Fontao L, Champliaud MF, Jaunin F, Frias MA, Favre B, Paulin D, Green KJ, Borradori L. 2006. New insights into the molecular basis of desmoplakin- and desmin-related cardiomyopathies. $J$ Cell Sci 119: 4974-4985.
Lariviere RC, Nguyen MD, Ribeiro-da-Silva A, Julien JP. 2002. Reduced number of unmyelinated sensory axons in peripherin null mice. $J$ Neurochem 81: 525-532.

Leonard DG, Gorham JD, Cole P, Greene LA, Ziff EB. 1988. A nerve growth factor-regulated messenger RNA encodes a new intermediate filament protein. J Cell Biol 106: 181-193.

Lepinoux-Chambaud C, Eyer J. 2013. Review on intermediate filaments of the nervous system and their pathological alterations. Histochem Cell Biol 140: 13-22.

Lewis SA, Balcarek JM, Krek V, Shelanski M, Cowan NJ. 1984. Sequence of a cDNA clone encoding mouse glial fibrillary acidic protein: Structural conservation of intermediate filaments. Proc Natl Acad Sci 81: $2743-2746$.

Li H, Capetanaki Y. 1994. An E box in the desmin promoter cooperates with the E box and MEF-2 sites of a distal enhancer to direct musclespecific transcription. EMBO J 13: 3580-3589.

Li H, Choudhary SK, Milner DJ, Munir MI, Kuisk IR, Capetanaki Y. 1994. Inhibition of desmin expression blocks myoblast fusion and interferes with the myogenic regulators MyoD and myogenin. J Cell Biol 124: 827-841.

Li Z, Colucci-Guyon E, Pincon-Raymond M, Mericskay M, Pournin S, Paulin D, Babinet C. 1996. Cardiovascular lesions and skeletal myopathy in mice lacking desmin. Dev Biol 175: 362-366.

Lian N, Wang W, Li L, Elefteriou F, Yang X. 2009. Vimentin inhibits ATF4mediated osteocalcin transcription and osteoblast differentiation. $J$ Biol Chem 284: 30518-30525.

Liem RK, Messing A. 2009. Dysfunctions of neuronal and glial intermediate filaments in disease. J Clin Invest 119: 1814-1824.

Mavroidis M, Capetanaki Y. 2002. Extensive induction of important mediators of fibrosis and dystrophic calcification in desmin-deficient cardiomyopathy. Am J Pathol 160: 943-952.

Mavroidis M, Davos CH, Psarras S, Varela A, Athanasiadis C, Katsimpoulas M, Kostavasili I, Maasch C, Vater A, van Tintelen JP, et al. 2015. Complement system modulation as a target for treatment of arrhythmogenic cardiomyopathy. Basic Res Cardiol 110: 485.

McLean J, Xiao S, Miyazaki K, Robertson J. 2008. A novel peripherin isoform generated by alternative translation is required for normal filament network formation. J Neurochem 104: 1663-1673.

McLean J, Liu HN, Miletic D, Weng YC, Rogaeva E, Zinman L, Kriz J, Robertson J. 2010. Distinct biochemical signatures characterize peripherin isoform expression in both traumatic neuronal injury and motor neuron disease. J Neurochem 114: 1177-1192.

Mermelstein CS, Martins ER, Portilho DM, Costa ML. 2007. Association between the muscle-specific proteins desmin and caveolin-3 in muscle cells. Cell Tissue Res 327: 343-351.

Messing A, Head MW, Galles K, Galbreath EJ, Goldman JE, Brenner M. 1998. Fatal encephalopathy with astrocyte inclusions in GFAP transgenic mice. Am J Pathol 152: 391-398.

Middeldorp J, Boer K, Sluijs JA, De Filippis L, Encha-Razavi F, Vescovi AL, Swaab DF, Aronica E, Hol EM. 2010. GFAPס in radial glia and subventricular zone progenitors in the developing human cortex. Development 137: 313-321.

Middeldorp J, Hol EM. 2011. GFAP in health and disease. Prog Neurobiol 93: $421-443$.

Milner DJ, Weitzer G, Tran D, Bradley A, Capetanaki Y. 1996. Disruption of muscle architecture and myocardial degeneration in mice lacking desmin. J Cell Biol 134: 1255-1270.

Milner DJ, Taffet GE, Wang X, Pham T, Tamura T, Hartley C, Gerdes AM, Capetanaki Y. 1999. The absence of desmin leads to cardiomyocyte hypertrophy and cardiac dilation with compromised systolic function. J Mol Cell Cardiol 31: 2063-2076.

Milner DJ, Mavroidis M, Weisleder N, Capetanaki Y. 2000. Desmin cytoskeleton linked to muscle mitochondrial distribution and respiratory function. J Cell Biol 150: 1283-1298.

Mitsui T, Kawajiri M, Kunishige M, Endo T, Akaike M, Aki K, Matsumoto T. 2000. Functional association between nicotinic acetylcholine recep- 
tor and sarcomeric proteins via actin and desmin filaments. $J$ Cell Biochem 77: 584-595.

Moeton M, Kanski R, Stassen OM, Sluijs JA, Geerts D, van Tijn P, Wiche G, van Strien ME, Hol EM. 2014. Silencing GFAP isoforms in astrocytoma cells disturbs laminin-dependent motility and cell adhesion. FASEB J 28: 2942-2954.

Moeton M, Stassen OMJA, Sluijs JA, van der Meer VW, Kluivers LJ, van Hoorn H, Schmidt T, Reits EA, van Strien ME. 2016. GFAP isoforms control intermediate filament network dynamics, cell morphology, and focal adhesions. Cell Mol Life Sci (in press). doi: 10.1007/ s00018-016-2239-5.

Mou L, Xu JY, Li W, Lei X, Wu Y, Xu G, Kong X, Xu GT. 2010. Identification of vimentin as a novel target of HSF4 in lens development and cataract by proteomic analysis. Invest Ophthalmol Vis Sci 51: 396-404.

Nielsen AL, Jorgensen AL. 2004. Self-assembly of the cytoskeletal glial fibrillary acidic protein is inhibited by an isoform-specific $\mathrm{C}$ terminus. J Biol Chem 279: 41537-41545.

Nieminen M, Henttinen T, Merinen M, Marttila-Ichihara F, Eriksson JE, Jalkanen S. 2006. Vimentin function in lymphocyte adhesion and transcellular migration. Nat Cell Biol 8: 156-162.

Nikolova V, Leimena C, McMahon AC, Tan JC, Chandar S, Jogia D, Kesteven SH, Michalicek J, Otway R, Verheyen F, et al. 2004. Defects in nuclear structure and function promote dilated cardiomyopathy in lamin A/C-deficient mice. J Clin Invest 113: 357-369.

Ogrodnik M, Salmonowicz H, Brown R, Turkowska J, Średniawa W, Pattabiraman S, Amen T, Abraham AC, Eichler N, Lyakhovetsky R, Kaganovich D. 2014. Dynamic JUNQ inclusion bodies are asymmetrically inherited in mammalian cell lines through the asymmetric partitioning of vimentin. Proc Natl Acad Sci 111: 8049-8854.

Olson EN, Capetanaki YG. 1989. Developmental regulation of intermediate filament and actin mRNAs during myogenesis is disrupted by oncogenic ras genes. Oncogene 4: 907-913.

O’Neill A, Williams MW, Resneck WG, Milner DJ, Capetanaki Y, Bloch RJ. 2002. Sarcolemmal organization in skeletal muscle lacking desmin: Evidence for cytokeratins associated with the membrane skeleton at costameres. Mol Biol Cell 13: 2347-2359.

Panagopoulou P, Davos CH, Milner DJ, Varela E, Cameron J, Mann DL, Capetanaki Y. 2008. Desmin mediates TNF- $\alpha$-induced aggregate formation and intercalated disk reorganization in heart failure. J Cell Biol 181: $761-775$.

Papathanasiou S, Rickelt S, Soriano ME, Schips T, Maier HJ, Davos CH, Varela A, Kaklamanis L, Mann DL, Capetanaki Y. 2015. A novel mechanism of cardiotropin through TNF- $\alpha$-induced ectopic expression of keratins K8 and K18. Nat Med 21: 1076-1084.

Parysek LM, McReynolds MA, Goldman RD, Ley CA. 1991. Some neural intermediate filaments contain both peripherin and the neurofilament proteins. J Neurosci Res 30: 80-91.

Pekny M. 2001. Astrocytic intermediate filaments: Lessons from GFAP and vimentin knock-out mice. Prog Brain Res 132: 23-30.

Perng MD, Wen SF, Gibbon T, Middeldorp J, Sluijs J, Hol EM, Quinlan RA. 2008. Glial fibrillary acidic protein filaments can tolerate the incorporation of assembly-compromised GFAP- $\delta$, but with consequences for filament organization and $\alpha \mathrm{B}$-crystallin association. Mol Biol Cell 19: 4521-4533.

Pfister O, Jain M, Liao R. 2005. Cell therapy in heart failure. Heart Fail Clin 1: 303-312.

Poon E, Howman EV, Newey SE, Davies KE. 2002. Association of syncoilin and desmin: Linking intermediate filament proteins to the dystrophin-associated protein complex. J Biol Chem 277: $3433-3439$.

Portier MM, de Néchaud B, Gros F. 1983. Peripherin, a new member of the intermediate filament protein family. Dev Neurosci 6: 335-344.

Price JC, Guan S, Burlingame A, Prusiner SB, Ghaemmaghami S. 2010. Analysis of proteome dynamics in the mouse brain. Proc Natl Acad Sci 107: $14508-14513$.

Psarras S, Mavroidis M, Sanoudou D, Davos CH, Xanthou G, Varela AE, Panoutsakopoulou V, Capetanaki Y. 2012. Regulation of adverse re- modelling by osteopontin in a genetic heart failure model. Eur Heart $J$ 33: $1954-1963$.

Quinlan RA, Brenner M, Goldman JE, Messing A. 2007. GFAP and its role in Alexander disease. Exp Cell Res 313: 2077-2087.

Ralston E, Lu Z, Biscocho N, Soumaka E, Mavroidis M, Prats C, Lomo T, Capetanaki Y, Ploug T. 2006. Blood vessels and desmin control the positioning of nuclei in skeletal muscle fibers. J Cell Physiol 209: 874882.

Rappaport L, Oliviero P, Samuel JL. 1998. Cytoskeleton and mitochondrial morphology and function. Mol Cell Biochem 184: 101-105.

Reeves SA, Helman LJ, Allison A, Israel MA. 1989. Molecular cloning and primary structure of human glial fibrillary acidic protein. Proc Natl Acad Sci 86: 5178-5182.

Rittling SR, Gibson CW, Ferrari S, Baserga R. 1985. The effect of cycloheximide on the expression of cell cycle dependent genes. Biochem Biophys Res Commun 132: 327-335.

Robertson J, Doroudchi MM, Nguyen MD, Durham HD, Strong MJ, Shaw G, Julien JP, Mushynski WE. 2003. A neurotoxic peripherin splice variant in a mouse model of ALS. J Cell Biol 160: 939-949.

Roelofs RF, Fischer DF, Houtman SH, Sluijs JA, Van Haren W, Van Leeuwen FW, Hol EM. 2005. Adult human subventricular, subgranular, and subpial zones contain astrocytes with a specialized intermediate filament cytoskeleton. Glia 52: 289-300.

Shah SB, Davis J, Weisleder N, Kostavassili I, McCulloch AD, Ralston E, Capetanaki Y, Lieber RL. 2004. Structural and functional roles of desmin in mouse skeletal muscle during passive deformation. Biophys J 86: $2993-3008$.

Shen W-J, Zaidi SK, Patel S, Cortez Y, Ueno M, Azhar R, Azhar S, Kraemer FB. 2012. Ablation of vimentin results in defective steroidogenesis. Endocrinology 153: 3249-3257.

Styers ML, Salazar G, Love R, Peden AA, Kowalczyk AP, Faundez V. 2004. The endo-lysosomal sorting machinery interacts with the intermediate filament cytoskeleton. Mol Biol Cell 15: 5369-5382.

Styers ML, Kowalczyk AP, Faundez V. 2005. Intermediate filaments and vesicular membrane traffic: The odd couple's first dance? Traffic 6: $359-365$.

Tapscott SJ, Bennett GS, Toyama Y, Kleinbart F, Holtzer H. 1981. Intermediate filament proteins in the developing chick spinal cord. Dev Biol 86: $40-54$.

Traub P. 1995. Intermediate filaments and gene regulation. Physiol Chem Phys Med NMR 27: 377-400.

Tsoupri E, Capetanaki Y. 2013. Muyospryn: A multifunctional desminassociated protein. Histochem Cell Biol 140: 55-63.

Uttam J, Hutton E, Coulombe PA, Anton-Lamprecht I, Yu QC, GeddeDahl T Jr, Fine JD, Fuchs E. 1996. The genetic basis of epidermolysis bullosa simplex with mottled pigmentation. Proc Natl Acad Sci 93: 9079-9084.

van Strien ME, Sluijs JA, Reynolds BA, Steindler DA, Aronica E, Hol EM. 2014. Isolation of neural progenitor cells from the human adult subventricular zone based on expression of the cell surface marker CD271. Stem Cells Transl Med 3: 470-480.

Weisleder N, Taffet GE, Capetanaki Y. 2004. Bcl-2 overexpression corrects mitochondrial defects and ameliorates inherited desmin null cardiomyopathy. Proc Natl Acad Sci 101: 769-774.

Weitzer G, Milner DJ, Kim JU, Bradley A, Capetanaki Y. 1995. Cytoskeletal control of myogenesis: A desmin null mutation blocks the myogenic pathway during embryonic stem cell differentiation. Dev Biol 172: $422-439$.

Wettstein G, Bellaye PS, Micheau O, Bonniaud P. 2012. Small heat shock proteins and the cytoskeleton: An essential interplay for cell integrity? Int J Biochem Cell Biol 44: 1680-1686.

Wilhelmsen K, Litjens SH, Kuikman I, Tshimbalanga N, Janssen H, van den Bout I, Raymond K, Sonnenberg A. 2005. Nesprin-3, a novel outer nuclear membrane protein, associates with the cytoskeletal linker protein plectin. J Cell Biol 171: 799-810.

Wilhelmsson U, Faiz M, de Pablo Y, Sjoqvist M, Andersson D, Widestrand A, Potokar M, Stenovec M, Smith PL, Shinjyo N, et al. 2012. Astrocytes 
negatively regulate neurogenesis through the Jagged1-mediated Notch pathway. Stem Cells 30: 2320-2329.

Witt SH, Labeit D, Granzier H, Labeit S, Witt CC. 2005. Dimerization of the cardiac ankyrin protein CARP: Implications for MARP titin-based signaling. J Muscle Res Cell Motil 26: 401-408.

Wong J, Oblinger MM. 1990. Differential regulation of peripherin and neurofilament gene expression in regenerating rat DRG neurons. $J$ Neurosci Res 27: 332-341.

Xiao S, McLean J, Robertson J. 2006. Neuronal intermediate filaments and ALS: A new look at an old question. Biochim Biophys Acta 1762: $1001-1012$.

Xiao S, Tjostheim S, Sanelli T, McLean JR, Horne P, Fan Y, Ravits J, Strong MJ, Robertson J. 2008. An aggregate-inducing peripherin isoform generated through intron retention is upregulated in amyotrophic lateral sclerosis and associated with disease pathology. J Neurosci 28: $1833-1840$.

Yoshida T, Sasaki M, Yoshida M, Namekawa M, Okamoto Y, Tsujino S, Sasayama H, Mizuta I, Nakagawa M, Alexander Disease Study Group in Japan. 2011. Nationwide survey of Alexander disease in Japan and proposed new guidelines for diagnosis. J Neurol 258: 1998-2008.

Zehner ZE, Paterson BM. 1983. Characterization of the chicken vimentin gene: Single copy gene producing multiple mRNAs. Proc Natl Acad Sci 80: $911-915$.

Zhao J, Liem RK. 2016. $\alpha$-Internexin and peripherin: Expression, assembly, functions, and roles in disease. Methods Enzymol 568: $477-507$. 


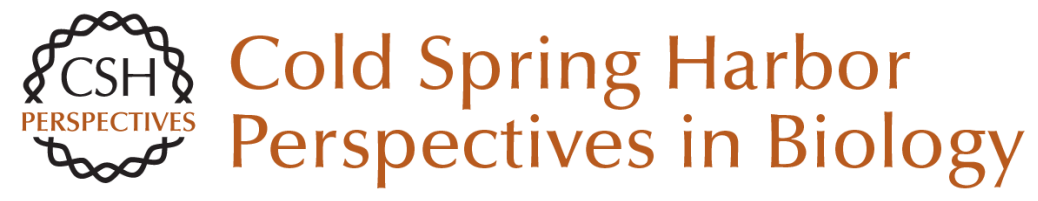

\section{Type III Intermediate Filaments Desmin, Glial Fibrillary Acidic Protein (GFAP), Vimentin, and Peripherin}

Elly M. Hol and Yassemi Capetanaki

Cold Spring Harb Perspect Biol 2017; doi: 10.1101/cshperspect.a021642

Subject Collection The Cytoskeleton

Microtubules and Microtubule-Associated

Proteins

Holly V. Goodson and Erin M. Jonasson

Motor Proteins

H. Lee Sweeney and Erika L.F. Holzbaur

Myosin-Driven Intracellular Transport Margaret A. Titus

The Actin Cytoskeleton and Actin-Based Motility Tatyana Svitkina

Mechanical Properties of the Cytoskeleton and Cells

Adrian F. Pegoraro, Paul Janmey and David A. Weitz

Intermediate Filaments and the Regulation of Cell Motility during Regeneration and Wound Healing Fang Cheng and John E. Eriksson

Intermediate Filaments and the Plasma Membrane Jonathan C.R. Jones, Chen Yuan Kam, Robert M. Harmon, et al.

\section{Overview of the Cytoskeleton from an \\ Evolutionary Perspective}

Thomas D. Pollard and Robert D. Goldman

Types I and II Keratin Intermediate Filaments Justin T. Jacob, Pierre A. Coulombe, Raymond Kwan, et al.

Muscle Contraction H. Lee Sweeney and David W. Hammers

Type III Intermediate Filaments Desmin, Glial Fibrillary Acidic Protein (GFAP), Vimentin, and Peripherin Elly M. Hol and Yassemi Capetanaki

Cytokinesis in Metazoa and Fungi Michael Glotzer

Ciliary Motility: Regulation of Axonemal Dynein Motors

Rasagnya Viswanadha, Winfield S. Sale and Mary E. Porter

Actin-Based Adhesion Modules Mediate Cell Interactions with the Extracellular Matrix and Neighboring Cells Alexia I. Bachir, Alan Rick Horwitz, W. James Nelson, et al.

For additional articles in this collection, see http://cshperspectives.cshlp.org/cgi/collection/

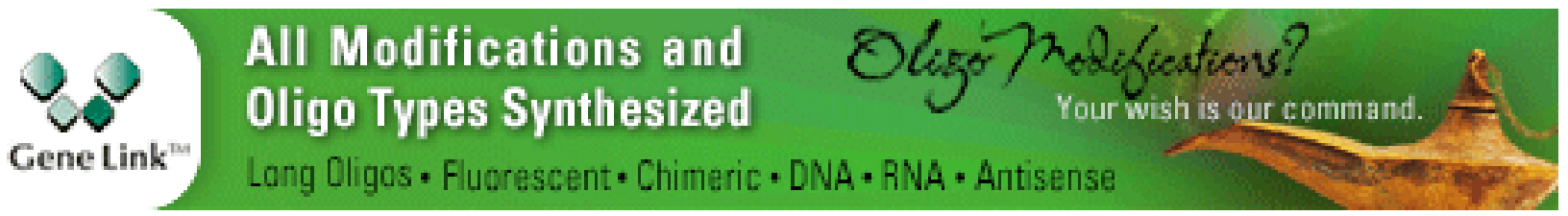


Intracellular Motility of Intermediate Filaments Rudolf E. Leube, Marcin Moch and Reinhard Windoffer
Microtubule-Based Transport and the Distribution, Tethering, and Organization of Organelles Kari Barlan and Vladimir I. Gelfand

For additional articles in this collection, see http://cshperspectives.cshlp.org/cgi/collection/

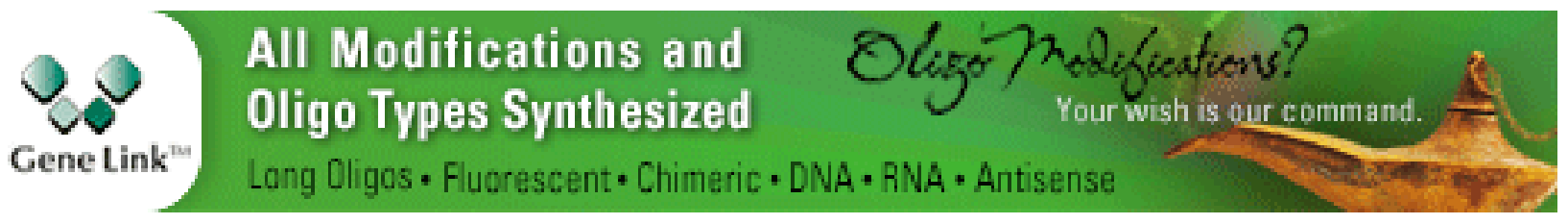

Copyright @ 2017 Cold Spring Harbor Laboratory Press; all rights reserved 